\title{
Rascunho: a presença do papel, da escuta e do tempo
}

Silvio Ferraz ${ }^{1}$

USP - Fapesp - Cnpq silvioferraz@usp.br 2020 


\section{Resumo}

Neste texto, que segue em fluxo de vai e vem, quase metáfora do processo composicional que narra, faço um apanhado de procedimentos composicionais recorrentes em meu trabalho de criação e que tem por ponto de partida o canto dos pássaros e modelos simples como princípio de gênese ritmo-melódica e mesmo harmônica. Em sua parte central, apresento a fundamentação teórica em uma leitura poética (relacionada não à filosofia ou teorias, mas a modelos de criação), com base na alagmática proposta por Gilbert Simondon em seu L'individuation à la lumière des notions de forme et d'information e no conjunto de aulas reunidas no livro Imagination et Invention. Busco deste modo pensar a continuidade musical entre heterogêneos por consistência local, em alternativa à noção tradicional de unidade lógica e ideal entre homogêneos.

Palavras-chave: Canto de pássaro; Simondon; composição musical; processo de criação.

\section{Abstract}

In this text, which was written in a back-and-forth flow, almost a metaphor for the compositional process that he narrates, I tried to put on a list of recurring compositional procedures in my creative work, which has as its starting point the bird song and simple models as a principle of melodic and rhythmic and even harmonic genesis. In its core, I present the theoretical foundation in a poetic reading (related not to philosophy or theories, but to models of creation), based on the Alagmatics proposed by Gilbert Simondon in his book L'individuation à la lumière des notions de forme et $d$ 'information and Imagination et Invention. In this way, I seek to think of musical continuity among heterogeneous individuals by local consistency, as an alternative to the traditional notion of logical and ideal unity among homogeneous ones.

Keywords: Bird songs; Simondon; musical composition; creative process. 
Este texto segue o fluxo de vai e vem do processo composicional que ele narra. Vai de pequenas narrativas de criação de alguns trabalhos específicos, passa por parênteses que flertam com a filosofia e poderia ainda passar por outros lugares. Não segue assim uma continuidade ideal ou mesmo retórica, mas a continuidade concreta dos agenciamentos. Colisão de quase disparates, acoplamento de fragmentos ora longos, ora curtos. Tudo apontando para sentido diferente, em uma operação muito próxima daquela que emprego em meu processo de escrita musical: o material que emprego e sua variabilidade, os momentos mais e os menos estáveis, as grandes praias sem movimento, os turbilhões caóticos etc.

\section{Os pássaros de Jacques Vielliard}

Em 2008 escrevi minha tese de livre-docência que trazia como subtítulo "Notas do caderno amarelo: a paixão do rascunho". A ideia ali era a de que, tendo como minha primeira prática artística as artes plásticas, minha paixão ao escrever música não estava apenas no resultado musical de uma peça, mas na quantidade de papel rabiscado que deixava para trás durante seu processo de nascimento. Nas cores, velocidade dos rabiscos, alguns momentos quase apagados, outros com marca forte do lápis, folhas de tamanhos diversos etc. Uma presença forte do desenho, como um grafite em um muro, contracenando com o som; o som como uma marca deixada por um movimento de lápis. Esta relação com o visual poderia esconder a presença do tempo, mas, pelo contrário, cada passo do processo composicional, cada pequeno rabisco, sobrevivia como marca de um desdobramento temporal a qual pretendia manter audível em minhas peças. Cada peça seria, assim, como que a descrição de sua trajetória de nascimento. Um processo que me faz lembrar a ideia de Pablo Picasso de que "pintamos a barba de um personagem, ela é ruiva, e este ruivo leva a rearranjar todo o conjunto do que já estava desenhado, a repintar todo seu entorno como que por uma reação em cadeia" (PICASSO, 1998, p.171). O tempo está aqui presente nesta reação em cadeia. Esta presença do tempo é uma constante entre artistas plásticos do século $\mathrm{XX}$, que, ao invés de apagar os traços dos percursos pelo contrário, os evidenciam. São percursos anamórficos diversos, de deformação de toda forma preestabelecida. Em Francis Bacon, em Giacometti, em Paul Klee. Deixar as marcas do tempo. Na música estas marcas muitas vezes não sobem ao palco, elas morrem em cadernos e cadernos, folhas e folhas de rascunhos, cálculos diversos feitos ao computador, e resta apenas o pálido tempo de sucessão de eventos realizados por algo ou alguém que converta símbolos visuais em sons.

Em 1986 conheci o ornitólogo Jacques Vielliard. Em uma manhã de visita ao acervo do laboratório de bioacústica da Unicamp, fez-me ouvir uma longa série de cantos de pássaros. Voltei para casa com duas fitas $\mathrm{K} 7$ repletas desses cantos, um artigo sobre beija-flores, a fotocópia de um livro de ornitologia voltado ao canto dos pássaros e uma ideia que Vielliard me fez ouvir e reouvir, o modo de canto de um garrinchão (Thryothorus leucotis): uma primeira frase curta, apenas três sílabas longas, uma delas centrada 
sobre uma mesma frequência, como se fosse um centro (seu som optimal) ${ }^{2}$, uma segunda mais complexa, ainda com o mesmo som optimal, e, seguindo um curto silêncio, uma terceira frase enunciada como um pequeno grito (fá-dó), prolongada e repetida.

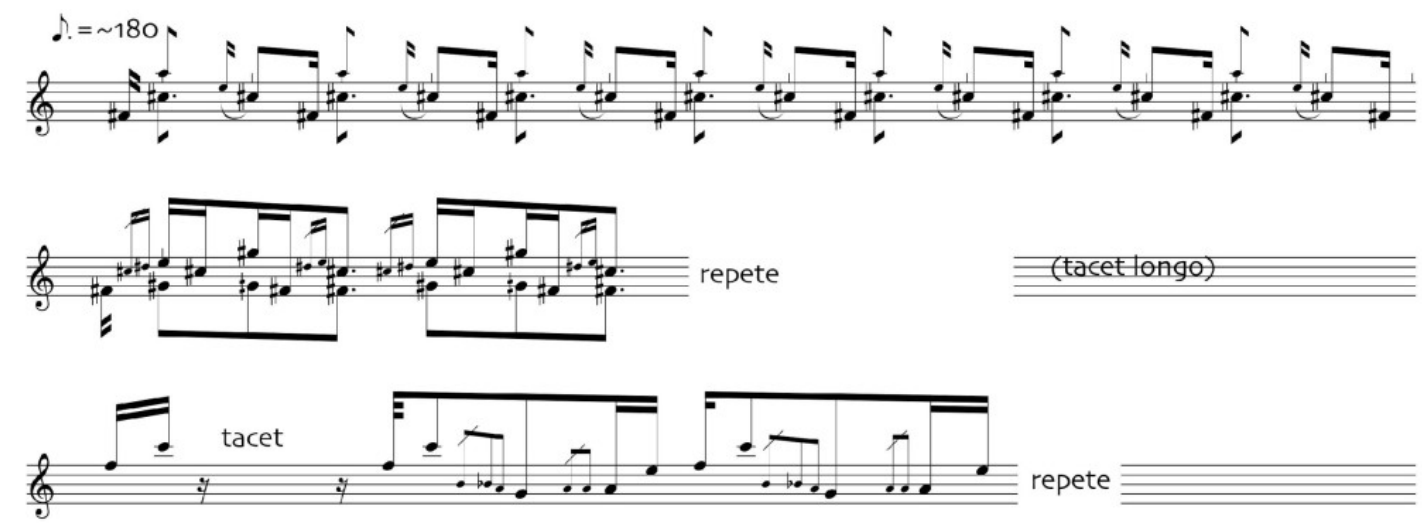

Fig. 1: Pequena sequência de canto de um garrinchão, em gravação realizada por Jacques Vielliard, hoje disponivel em CD (VIELLIARD, 1995, faixa 46)³.

Vielliard me fez ouvir outros cantos e transcrevi alguns em minha dissertação de mestrado. Mais do que a permutação de frases, como salientou François-Bernard Mâche em seu Musique, Mythe, Nature (1986), para mim o que chamava a atenção nestes cantos era a recursividade, as pequenas deformações que o canto sofria e o modo como, a partir de pequenos giros, surgiam escapadas que levavam esta melodia adiante.
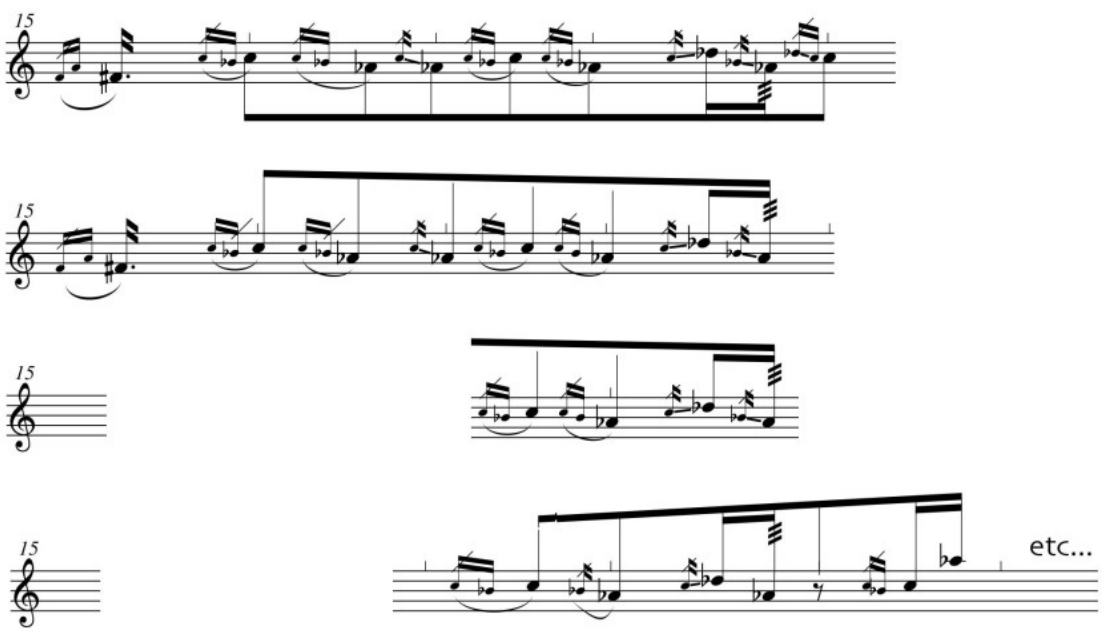

Fig. 2: Pequena sequência de canto de um sabiá-coleira, em gravação realizada por Johan Dalgas Frisch (1963).

\footnotetext{
2 A frequência optimal seria aquela recorrente no canto do pássaro e com uma certa posição privilegiada de finalização ou início. No caso do garrinchão registrado por Vielliard, está entre as notas do e do\# (quando comparados os três fragmentos anotados). Na dissertação de mestrado que escrevi analisando estes cantos de pássaro, as frequências optimais foram denominadas "notas nucleares", já com um propósito composicional.

3 Sem recursos fáceis de análise de áudio, na época fiz a transcrição com um pequeno gravador que me permitia modificar a velocidade para anotar, a partir da escuta, o que talvez fosse uma partitura daquele canto. Mas, como o que me interessava era o canto tal qual o humano 0 ouve, a escuta e transcrição não significaram más ferramentas, pelo contrário.
} 
De um lado, a leitura de Mâche, que se adequava bastante ao sabiá-poliglota, permutando um grande conjunto de frases, de outro, o que me alertara Vielliard sobre os pássaros jovens em sua primeira primavera, com cantos totalmente experimentais, com sequências por vezes confusas, mas altamente móveis e progressivas.

Há diversas ressalvas quanto ao uso do canto de pássaros para a composição de uma linha melódica. Claro que as referências são Vivaldi, Stravinsky, Messiaen e Hercule Florence (VIELLIARD, 1993). Os modos diversos de anotar e de pensar o estilo pássaro. Não é que eu me aproprie, como a partitura da figura acima, de um canto anotado e simplesmente o transponha para instrumentos. Há no processo de anotar muita transformação.

Uma primeira questão é a escolha de partir sempre da escuta humana que se faz do canto, e não do canto traduzido por ferramentas, como analisadores de espectro. Afinal de contas, fomos atraídos para o canto dentro do limite de nossa escuta. Uma análise em sonograma pode ajudar a compreender os cantos, mas pode falsear. Na análise de sonograma, o que temos é sempre um pássaro glissador. O que ouvimos como uma nota é de fato um ponto em uma curva. Encontrar onde fica a nota que estamos escutando é um jogo complicado. Ora escolhemos uma nota, ora outra. Ao transcrever por escuta um neuma de pássaro, este parece ser cantado com intervalos próximos, porque ouvimos as últimas notas que se distinguem de um glissando, que é sempre mais amplo que o intervalo que captamos, daí que o que escutamos como tom é de fato um trítono ou algo parecido. O que para a escuta humana é uma simples segunda maior pode estar escondendo um glissando que passou por extremos, por sétimas, nonas. É então que refaço estas imprecisões na escrita, transportando as notas para estes extremos, e mesmo para mais longe que a simples sétima que consegui visualizar no sonograma. $E$ as pequenas passagens rugosas que ouço no canto dos pássaros, as transformo em saltos, em intervalos de sétima ou nona, jeito de fazer aparecer os batimentos, a rugosidade do que ouvi. Observo que, transcrevendo para uma música instrumental, estes cantos de pássaros que saltam muito podem ser pensados para mais de um instrumento ou região de timbre em um mesmo instrumento; maneira de refazer o som meio disperso, que vem de mais de um lugar, que tem timbre e projeção diferente em cada sílaba. Além disso, ainda teria as apojaturas que definem o "estilo pássaro", o perfil amplo dos glissandos abrem brecha para colocar mais notas, para escrever pequenas frases em zigue-zague etc. É importante lembrar sempre que muitos dos pássaros que por vezes ouvimos com canto grave estão, de fato, cantando em regiões extremamente agudas, como o caso dos sabiás. 

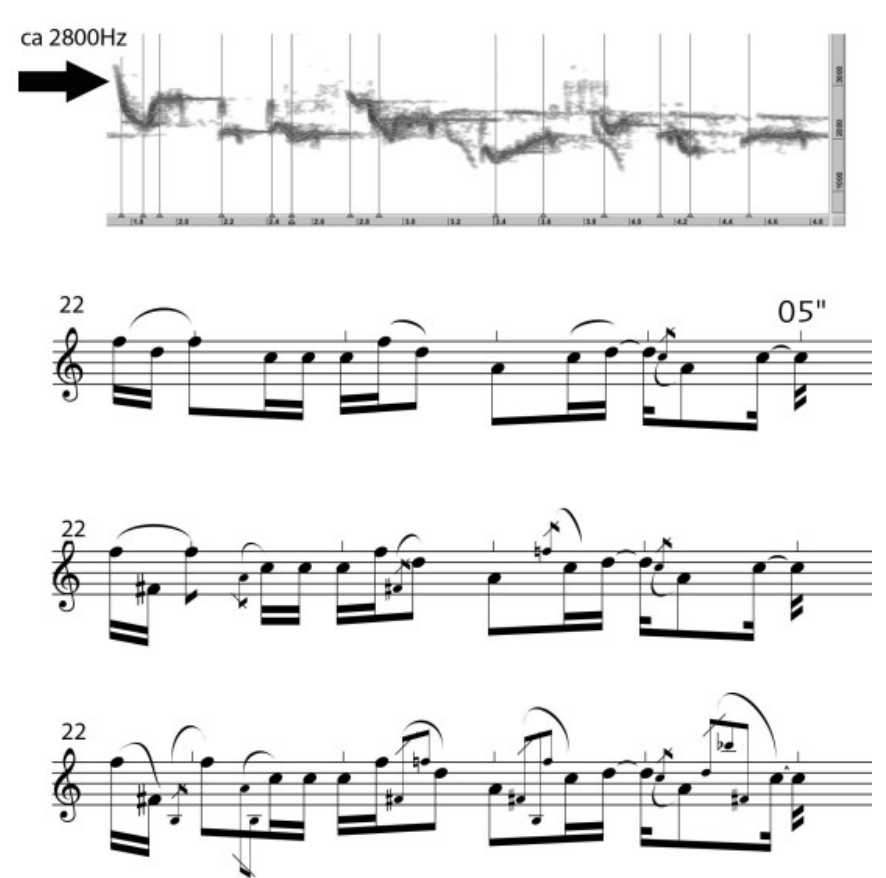

Fig. 3: Sonograma do canto de sabiá-laranjeira e suas transcrições possíveis. Vale observar que o sabiá é um pássaro cujo canto nos é grave, no entanto ele canta na região de $2500 \mathrm{~Hz}$.

Uma segunda questão ligada à notação do canto dos pássaros diz respeito à sua sequência melódica. Messiaen gostava de dizer o quanto um canto de pássaro vem atravessado pela hora, umidade, luminosidade, e deformado pela nossa escuta e pelas possibilidades diatônicas da escrita instrumental que empregava. A partir desta ideia de Messiaen, penso o quanto a escuta que temos do canto de um pássaro vem atravessada pela escuta de todo o seu entorno. É então que, em minha escrita musical, ao imaginar estes cantos, os sobreponho, justaponho e interrompo, de modo a inventar um pássaro jovem que procura seu canto de modo incessante e exploratório.

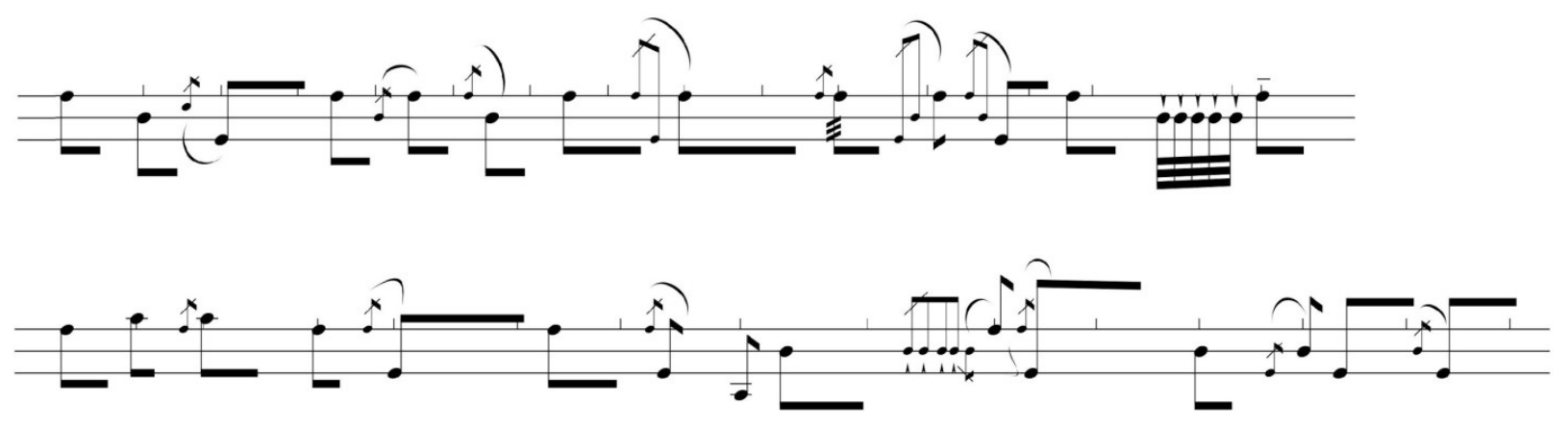

Fig. 4: Transposição sem altura definida de canto de pássaro, observando as notas fixas, as apojaturas que evoluem, as incrustações (trêmulo, notas repetidas), as paradas sobre duas notas (neste exemplo, ora no agudo, ora no grave, separadas em uma escrita polifônica).

O que me interessa bastante neste modo de trabalhar é que ele deixa os traços de seu percurso de expansão, como uma espécie de exploração em torno de um primeiro ponto escolhido. E tais exemplos não vêm apenas dos pássaros, em um Akazéhé a 
uma voz, canção registrada em 1968 no disco Musique traditionnelles vivantes ${ }^{4}$, canto tradicional Burundi, encontrei um modo semelhante de exploração e progressão. Notei a comum recursivididade de construção melódica, sempre retomando uma ponto de partida, voltando a este ponto ou um passo atrás.

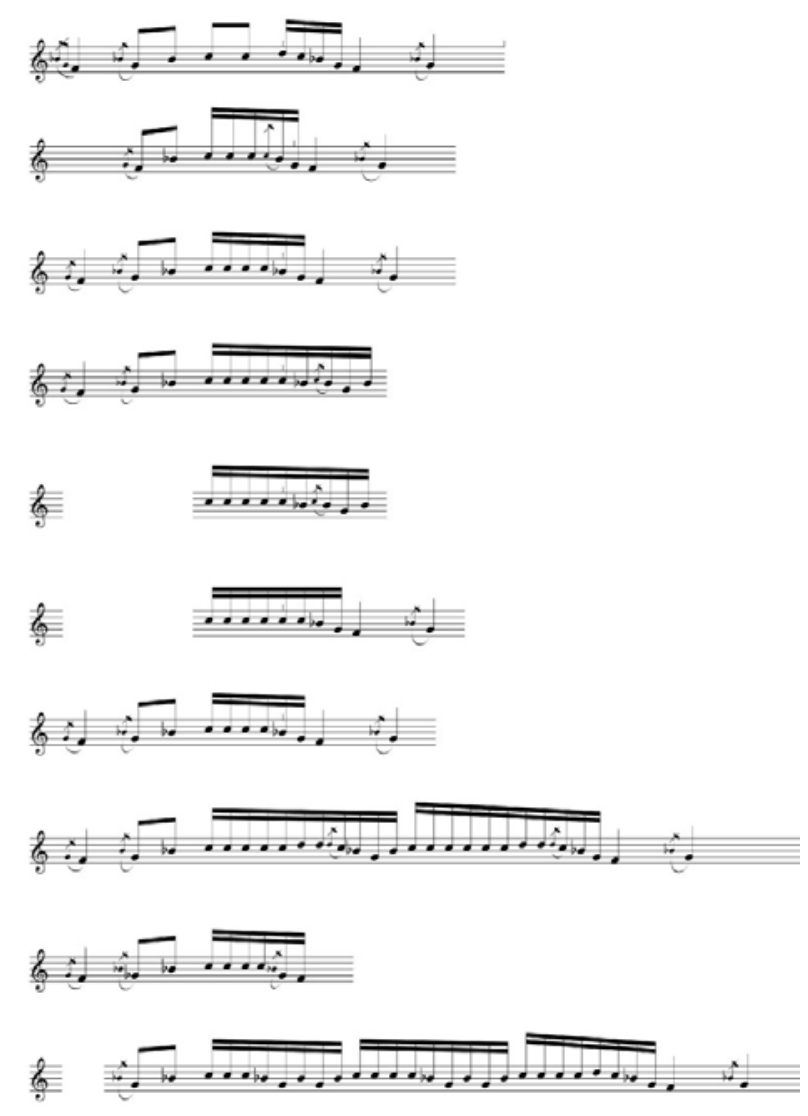

Fig. 5: Pequena sequência de Akazéhé a uma voz, a partir de gravação do disco Musiques traditionnelles vivantes. A anotação busca demonstrar mecanismo de adição e subtração, de prolongamentos e encurtamento de frases, a partir de modelo de notação proposto por N. Ruwet em Méthode d'Analyse en Musicologie (1966).

Para anotação destas pequenas sequências, optei na época pela análise paradigmática proposta por Nicolas Ruwet (1966) para um Geisslerlied alemão do século XIV. Esta notação acabou por me fornecer um método para desdobrar sequências de modo centrípeto, partindo da repetição de módulos, e lentamente acrescentar novos módulos, de maneira a se afastar do primeiro. A cada repetição do módulo, permitia também imaginar processos de sua deformação. Não se tratava, assim, de variações, mas realmente de deformações, podendo mesmo o original se desfazer por completo, tal qual um prolongamento analítico, conforme leitura do matemático Albert Lautman em seu Essai sur les notions de structure et d'existence en mathématique, livro retomado por Gilles Deleuze em uma de suas aulas de 1982:

[...] tome [um ponto] como centro de um círculo e, no interior deste círculo, tome um outro ponto /.../ e por sua vez trate este ponto como centro de um novo círculo. Obtém-se assim uma sequência de séries convergentes $/ . . . / O$ que se

4 Disco gravado por Michel Vuylsteke entre 1967 e 1970 em Ngozi, Bujumbura, Bukirasazi e Kayanza (Burundi). 
consegue com isto? Constitui-se um novo espaço na corrente desta operação, com uma sucessão de operações locais, passo a passo. (DELEUZE, 1982, on-line).

É esse modo de trabalho que marca meu processo composicional desde o final da década de 1980 e posso encontrá-lo em praticamente todos os meus rascunhos. Um método que me permitiu compor pensando sempre a partir de um ponto impreciso. Começar uma composição a qualquer momento, com qualquer material, sem dar importância a um material em detrimento de outro. As ideias surgindo do encontro entre desenho e som. Um desenho que teria uma escuta por trás, o olho comprometido de antemão com os ouvidos. Escuta de linhas, escuta de blocos, de matizes sonoros e coloridos.

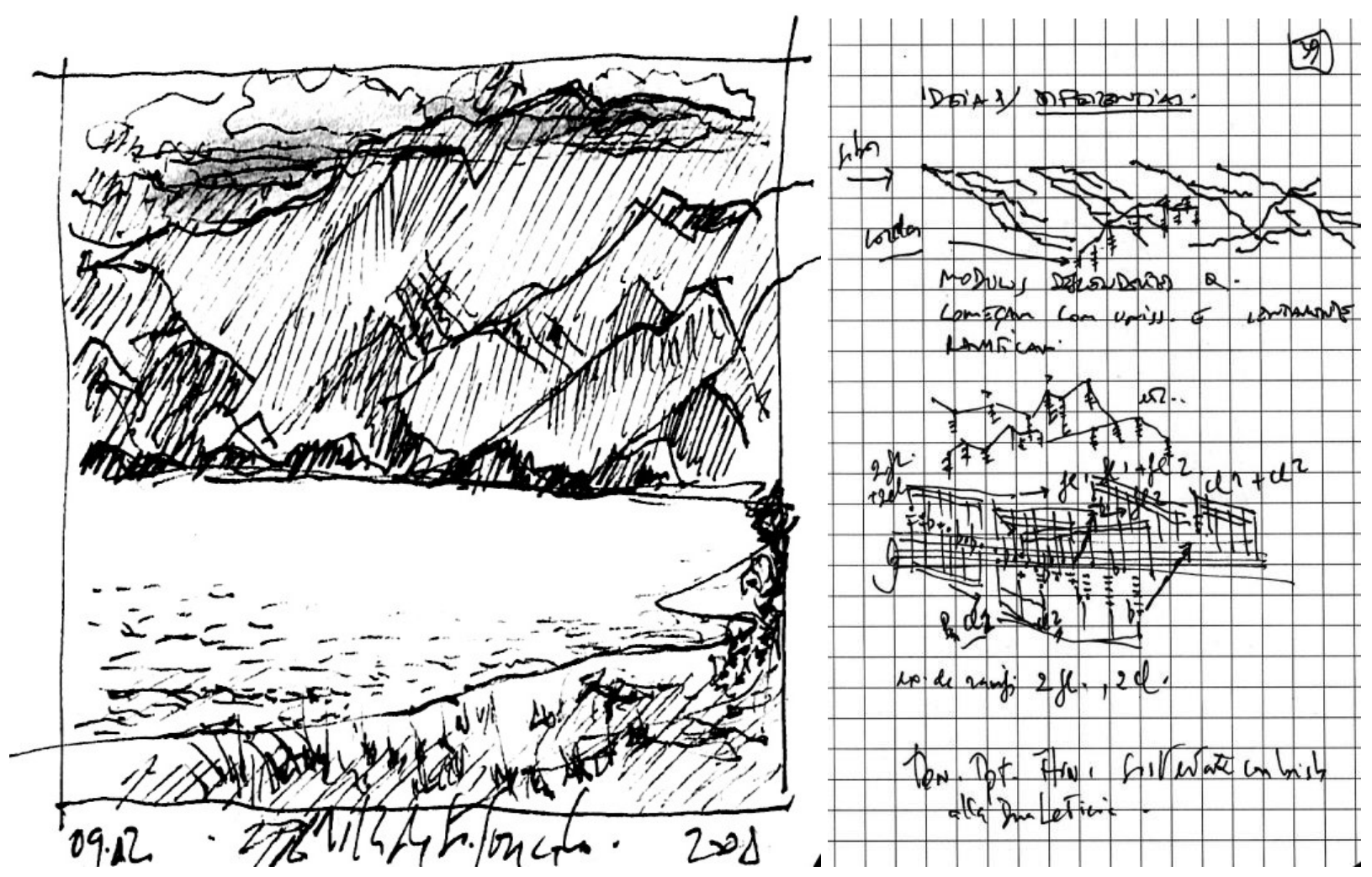

Fig. 6: Desenho rápido da Serra do Mar, vista da praia de São Gonçalo, Paraty, e ideia derivada com linhas descendentes e possivel transcrição em notação de alturas.

Como disse, neste processo, o material composicional pode ser proveniente de qualquer lugar, pode ser qualquer coisa, ele é um simples ponto de partida. Mas, ao longo de minha prática composicional, eles foram sendo selecionados: cantos de pássaros; música indígena brasileira; tambores da música da África Central; músicas coletivas brasileiras; sons diversos, como os carros de boi, o mar, o vento, os sinos, coro de sapos, os sons raspados de gangorras e balanços de parques públicos, o ritmo indeciso e as falas ofegantes. Destes elementos, destacaria dois: os pássaros, e as sequências rítmicas pulsantes - muito disto atravessado pela proposta de compreensão realizada por Simha Arom em seu artigo "Une méthode pour la transcription de polyphonies et polyrythmies de tradition orale", de 1973. 
Conheci a proposta de Arom lendo sobre Luciano Berio, no livro Luciano Berio: Chemins en musique, de Ivanka Stoïanova. Na composição de sua obra Coro, Berio se valeu do modo de pensamento polirrítmico estudado por Arom na música dos Banda-Linda, da República Centro-Africana (STOÏANOVA, 1985, p.193-197).

Nesta música Arom observou a construção de estruturas complexas a partir da sobreposição de ciclos simples e que muitas vezes não cabem em nossa notação tradicional de compassos. ${ }^{5}$

Encontrei tais estruturas em diversas manifestações periódicas que me serviram de imagens composicionais: o vai e vem do balanço do mar, dos toques de sinos em igrejas, da cantoria de sapos. Um largo conjunto de materiais que alimentam toda uma máquina que compõe a cor rítmico-sonora e o fluxo nas músicas que escrevo.

É assim que compus, em 2013, o quarteto de cordas Pássaros de Corda, que teve estreia apenas em 2019. A peça faz parte do ciclo que denominei Kairos, obras em que não há um plano geral definido de antemão, mas apenas decisões locais a partir da anamorfose de um primeiro material, do surgimento de outros e de ações que impõem cortes. Busco assim a continuidade não por meio da identidade entre materiais (similaridade ou contiguidade), mas pelo corte, pela força de conexão do istmo que desenha um corte .

É deste modo que comecei a compor este quarteto, sem um plano geral, tendo apenas um ou alguns pontos de partida, mas todos guiados por uma metáfora de onda modulante, a harmonia do Crucifixus da Missa em Si menor (BWV 232), de Bach, modulada por frases em estilo pássaro. Uma ideia geral um tanto quanto truncada, disforme: a recursividade de uma wavetable, o modelo do canto de pássaros, tudo conduzido por um fluxo, vez ou outra cortado, um fluxo pensado em quatro andamentos sobrepostos, cada instrumento um andamento, ora todos em fase, ora fora de fase. Deixei-me a partir daí às decisões locais, à decisão final de incluir um solo de violino, de distribuir um outro solo entre os dois violinos, de criar um par de compassos de notas longas estranhas ao passo harmônico ao qual sucede etc.

Decisões e decisões, tudo em ressonância também com alguns passos que minha vida vinha tomando naquele momento. Não trago aqui estes dados para que sejam procurados dentro da peça, mas para relatar um processo composicional em que não se tem um plano inicial fechado e em que toda e qualquer turbulência externa pode alterar o curso da composição, ou seja, nenhuma estrutura, nenhum plano, nenhuma noção de unidade ou coerência, mas a necessidade de a todo momento pensar um pouco como

\footnotetext{
5 A questão da notação rítmica é bastante discutida no domínio da etnomusicologia, ressaltando aqui dois trabalhos, o de Marcos Branda Lacerda e Kofi Agawu, respectivamente nos livros Música instrumental do Benin (LACERDA, 2014, pp.43-57) e Representing African Music (AGAWU, 2003, pp.71-95).

6 Já há um bom tempo observo três caminhos em meu processo composicional, distinguindo os ritornelos, os lamentos e os Kairos. Kairos de fato deveria se chamar Caos. Os ritornelos são peças em que há (1) grande e rápida alternância nos modos de ataque, (2) tratamento da tessitura por grandes saltos a partir de cantos de pássaros, (3) escrita rítmica micrométrica e (4) desdobramento de material composicional por módulos recursivos e prolongamento analítico. Os lamentos são peças lentas, módulos longos, geralmente conduzidos por uma linha de passus duriusculus. A harmonia das peças geralmente é conduzida por reescrita e, no mais das vezes, a base é um dos motetos de passo do compositor mineiro do século XVIII-XIX Manoel Dias de Oliveira. Os Kairos têm por base a decisão e os pontos de ruptura, que tratei em artigo intitulado justamente "Kairos: ponto de ruptura".
} 
Picasso, isto é, pintar como quem trabalha uma reação em cadeia. Nesta toada, como se diz, é que numa leitura de entrevista com Gérard Grisey, sobre a ideia de música liminar, me veio o incômodo de muitas vezes estar escrevendo uma música em que os desafios vão desaparecendo e dando lugar a técnicas já recorrentes. $O$ liminar diz respeito a recolocar em jogo o desafio, o abismo, e se desfazer do medo. Neste sentido é que, a certa altura da composição, resolvi fazer um grande corte ao acaso e inserir três compassos de estatismo, quase nada, tudo parado, lembrando um pouco Grisey e sua surpresa com alguns momentos excessivamente simples de seus Quatre chants pour franchir le seuil.

Foi neste mesmo sentido que um dia, escutando o Allegro Assai da 3ạa Sonata em Dó maior para violino solo (BWV 1005) de J. S. Bach, com uma especial atenção a uma passagem de bariolages, resolvi incorporar uma reescrita desta passagem como último solo, passando do segundo ao primeiro violino, com uma inserção súbita de uso de quartos de tons sem que em nenhum momento da peça este universo tenha sido aludido.

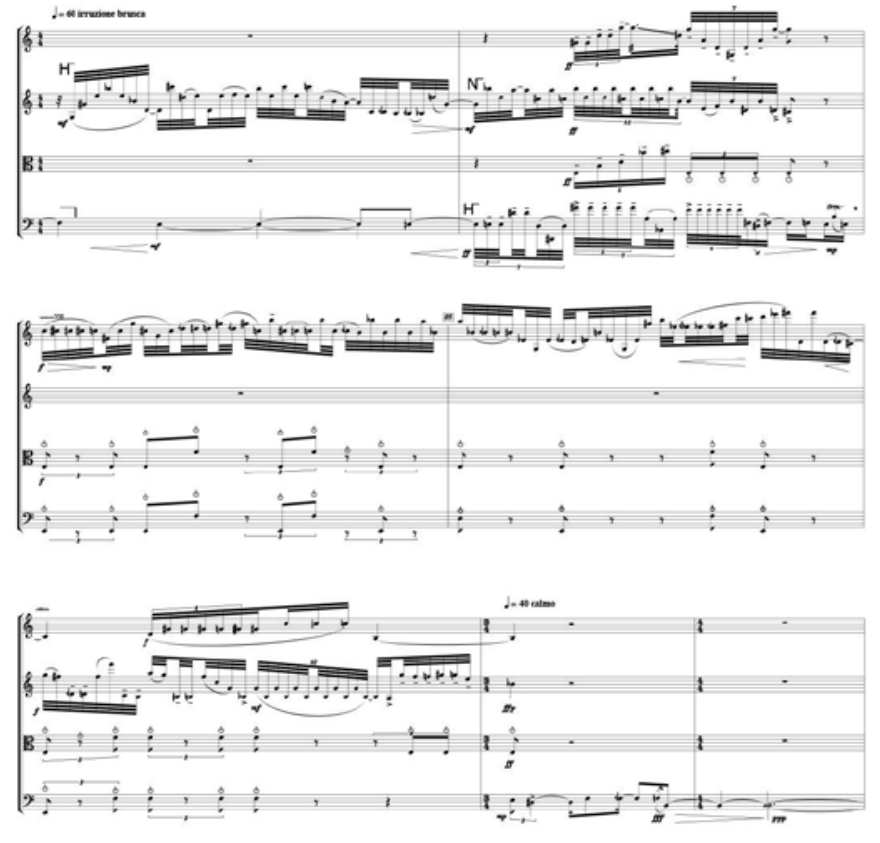

Fig. 7: Momento final de Pássaros de corda, para quarteto de cordas.

\section{Corte e modulação: forma em formação}

A ideia de corte que comentei mais acima neste artigo diz respeito ao corte brusco, não como modo de separar dois estados ou momentos, mas como modo de conectar. Esta ideia se relaciona à de reação em cadeia e tem por base o curso de Gilbert Simondon Imagination et Invention (1965 e 1966). O seu ponto de partida é sem dúvida a noção de imagem trabalhada por Henri Bergson em Matéria e Memória. Da leitura de Bergson, o que me interessa aqui e que vejo retomado em Simondon é a noção de imagem. As imagens não seriam uma representação interna de um mundo externo, mas a ação mesma que constitui o que chamamos de matéria, um "conjunto das imagens" e a 
"percepção da matéria" como "essas mesmas imagens relacionadas à ações possíveis de uma certa imagem determinada, meu corpo" (BERGSON, 1990, p.13 e 56-57).

O que Simondon acrescentaria à proposta de Bergson é o dinamismo da constituição, autonomização, amplificação e ruptura destas imagens, para as quais distingue três fases da constituição da imagem: imaginação, percepção e lembrança. Imagem é aquilo que dá ou se percebe "quando abro meus sentidos" (BERGSON, 1990, p.9). Elas teriam como primeira faculdade o movimento: as imagens se movem, transitam e se chocam umas com as outras. É neste sentido que Bergson define suas imagens-ação: elas são motoras e nascem do primeiro impacto de um corpo com outro.

Simondon (2008, p.9) retoma esta ideia ao dizer que as imagens são um "quasi-organismo /.../ que habitam o sujeito e que nele se desenvolvem com uma relativa independência". Se em Bergson, no entanto, ainda havia uma distinção entre imagens, como imagem visual, mental, material, esquemas etc., Simondon deixa de distinguir diferentes espécies de imagem para pensar todas como "etapas de uma atividade única submetida ao processo de desenvolvimento" (SIMONDON, 2008, p.3).

O que me interessa aqui, para pensar a composição, está logo no início do curso de Simondon, quando propõe que, "em seu nascimento, a imagem é um feixe de tendências motoras, antecipação a longo termo da experiência do objeto" (SIMONDON, 2008 , p.1). São as imagens que nos servirão de sistema de acolhimento (de prontidão) para sinais que incidem dos mais diversos meios (interno, externo, intermediário) e que nascem e permanecem como operadores da interação entre organismo e meio (entre meio e meio) ${ }^{7}$.

De fato, o que observo, com base em leitura de outros textos de Simondon, é que estamos diante de um choque entre fluxos. Um fluxo entra em choque com outro (ou outros) e, nesse choque, temos uma modulação em que um fluxo disperso, de maior energia, é modulado por um de menor energia e maior regularidade, enquanto este é desgastado pelo anterior. Um modulado e um modulante.

Conforme Simondon (2008), estamos diante de uma primeira separação, o corpo que recebe a ação de um conjunto de forças (um fluxo de energia) se separa, conforme seu potencial de modulação (modulante ou modulado), da ação que recebe de outro corpo. Mas tal separação dá lugar ao nascimento de uma imagem específica, de maior permanência. Simondon distingue aqui signo e símbolo, este último é intrínseco à ação, diz respeito a uma relação analítica entre os fluxos, um símbolo sempre sendo relativo a no mínimo dois fluxos, diferentemente de um signo que para ele é um termo suplementar (arbitrário, convencionado, de semelhança intrínseca) acrescentado ao fluxo. A presença do signo estaria, por exemplo, no ato de explicação de alguma coisa, onde este discurso estruturado buscaria modular e orientar o potencial de transformação de um corpo e do choque entre outros fluxos. Apenas um parêntese: Uma explicação seria, assim, sempre uma busca de controle do potencial livre de um fluxo.

A leitura que realizo aqui tem outras referências as quais vale citar, sobretudo ao falar de meios, de imagens. Já citei Bergson, mas não podemos esquecer das proposições de Deleuze e Guattari em Mil Platôs, especificamente nos capítulos "Acerca do ritornelo" e "Devir-intenso, devir-animal, devir-imperceptível", e daquela que está na base tanto de Deleuze quanto de Simondon: o livro Milieu animal et milieu humain, de Jakob von Uexküll. É em Uexküll que uma noção mais ampla de meio é apresentada, não sendo o meio apenas aquilo que se apresenta, mas aquilo que é notavelmente presente. 
As forças moduladas se compondo em percepções. É a modulada quem percebe, é ela quem toma outro sentido. Ao permanecerem por um curto tempo no corpo modulado, as imagens moduladas, imagens-percepção (sempre na leitura que Simondon realiza de Bergson), se tornam independentes daquela imagens-ação, tecendo a partir de então um contraponto com outras imagens-ação. Importante observar que não há uma hierarquia entre um conjunto de imagens e outro. No processo de autonomização, todas as imagens podem ora ser moduladas, ora modular.

Simondon fala então das permanências de maior termo no corpo que recebeu o impacto, a ponto de constituírem o que chamará por lembranças, as imagens-souvenirs. Em uma rede exaustiva de exemplos, ele observa tais jogos presentes desde simples transdutores mecânicos, os díodos e tríodos, até seres vivos e grandes organismos, como um grupo social.

Desdobrando um tanto sua proposta, todo conjunto de imagens, fluxo de imagens, pode constituir um território, um fluxo estável. As imagens-lembrança (os símbolos) tendem à saturação, mas um outro fluxo de imagens pode interpor um impasse e desfazer a estabilidade provisória do fluxo. É frente a este impasse que se dá o que Simondon chama por invenção: um desvio. Para que o fluxo continue, é necessário o nascimento de uma operação, uma ferramenta. A água encontra seus desvios para seguir o curso de seu fluxo morro abaixo, o pensamento segue seu fluxo ou, como diz Simondon, "cada nova extensão do domínio de ação humana é marcada por uma invenção que autoriza uma sistemática de compatibilidade englobando este novo domínio". Esta conversão de conexões em símbolos abre, assim, "um sistema de conversões de ações, permitindo comparar e colocar umas em relação às outras" (SIMONDON, 2008, p.159).

Penso, assim, em uma paisagem sonoro-musical estável, contínua, lugar em que o fluxo é tal que mal se consegue distinguir objetos, onde há apenas a impressão de fluxo. Não conseguindo distinguir objetos, estes se fundem em uma trama sonora contínua, um longo pedal, uma nota suspensa no agudo... qualquer fluxo que não distinga mais de um objeto compreenderia, assim, uma prontidão para uma imagem, aqui a imagem de textura ${ }^{8}$. Se, ouvindo esta paisagem de uma nota longa, a ela eu venha a interpor uma quebra com uma inflexão, a nota longa cambaleia e nasce assim a ideia de figura. O que era permanente, sem movimento, ganha um contorno e se fixa como contorno. A inflexão, neste caso, separou um antes e um depois, um acima e um abaixo, um próximo e um distante e, sobretudo, uma escuta textural de fluxo de uma escuta figural de contorno. Uma sequência rítmica é uma figura, uma melodia é uma figura.

O que penso, a partir de Simondon, é uma relação entre textura e figura, não como duas categorias, mas como duas fases dos fluxos sonoros. Uma figura não apenas surge como figura, não se trata, assim, de uma categoria à parte, mas como que emergindo de um processo em que se faz figura a partir de um jogo entre no mínimo dois fluxos

8 É importante aqui distinguir textura sonora de textura musical, pois, ao optar por um paradigma do som (SOLOMOS, 2013), o que a música a partir de Ligeti propõe não é a textura no sentido aplicável às texturas harmônicas de Piston, resgatadas por Berry, mas, sim, um fenômeno de fusão próprio da cena-auditiva de certos fluxos sonoros. Neste sentido ver, quanto à percepção e fusão específica na escuta de de texturas sonoras ver DUNSBY, 1989; FERRAZ, 1991. Quanto à textura musical ver BERRY, 1987, e McDermott e Simoncelli (2011). 
de energia, um processo de mise-en-forme, a forma como "fronteira topológica de um sistema" (SIMONDON, 2005, p.45).

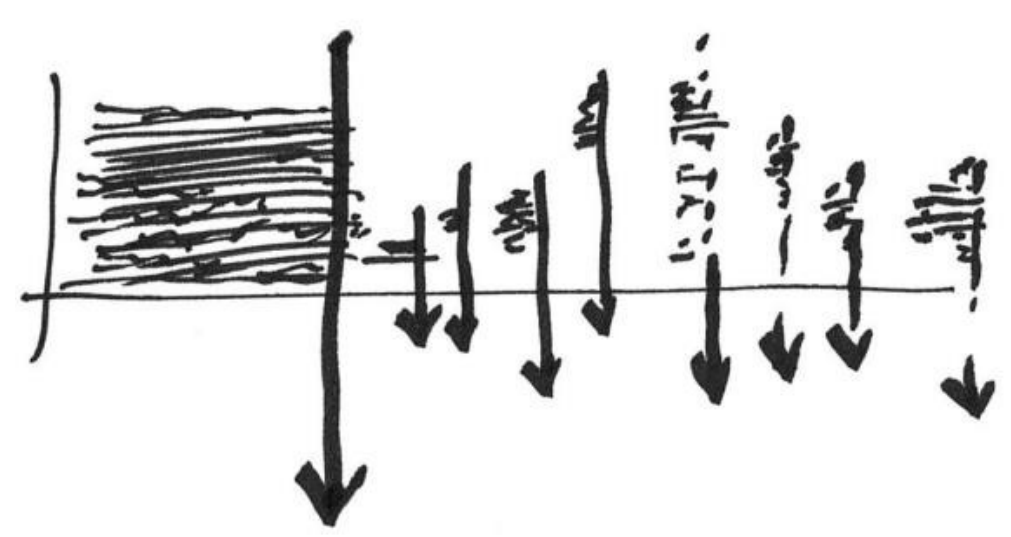

Fig. 8: Fluxo-textura de trama horizontal quebrada por turbulências e interrupções, fazendo emergir o fluxo-figuras.

Compreendendo o processo de imaginação com base em suas fases, as imagens se autonomizam dos corpos nos quais nasceram. Autonomizam-se enquanto operadores, seja por semelhança, seja por disposição, e permanecem como imagens-lembrança. Nesta fase as imagens se dispõem a aparecer a qualquer momento como operadoras de novas modulações, vindas de uma espécie de reservatório ausente. Poderia chamar tais imagens de imagens-gesto. O gesto seria esta imagem que relaciona a distância imagens que estiveram um dia próximas. O gesto é o sinal da presença do tempo. Ele fundamenta o tempo, fundado pelo corte da imagem-figura9.

Fundado e fundamentado o tempo das imagens, faltaria apenas um elemento para colocar o sistema em círculo, o que Simondon chamou de invenção, o afundamento do tempo ${ }^{10}$. O corte do fluxo sempre impõe um desvio. Ao interrompermos um fluxo de água, ela sempre encontra outros modos de escoar. Desviar para restabelecer a continuidade. Imagine uma polifonia densa e que de súbito irrompe um gesto brusco de corte, restando apenas uma nota do agudo como reencontrar a polifonia anterior na nota aguda posterior? Eis o que Simondon denomina invenção: o nascimento de um operador sensível ou intelectual. Pensando em uma escuta musical, o corte no presente impõe uma maior densidade de tempo e a ausência de corte, sua diminuição. A invenção é o lugar da duração, o lugar do tempo que Deleuze chamaria de um tempo intensivo.

Claro, cabe ao compositor ponderar: o excesso de corte leva ao desespero, é preciso espaço para processar a continuidade, ou ainda para observar sua responsabilidade e fundar um novo tempo, fundar um novo território. Já a ausência de corte levaria ao torpor, a refletir, procurando quaisquer coisas que ponham o movimento de volta. As imagens sempre em movimento, talvez esta seja a dinâmica do "desejo de música": o desejo de movimento no som.

9 Leituras pormenorizadas da noção de gesto foram trabalhadas pelos compositores Valéria Bonafé (2011) e Felipe Merker Castellani (2011). 10 Tais ideias de fundação, fundamentação e afundamento do tempo refletem as sínteses do tempo como trabalhadas em Diferença e Repetição por Gilles Deleuze e lidas de um ponto de vista composicional no artigo "Páginas sobre tempo e espaço" (FERRAZ, 2016). 


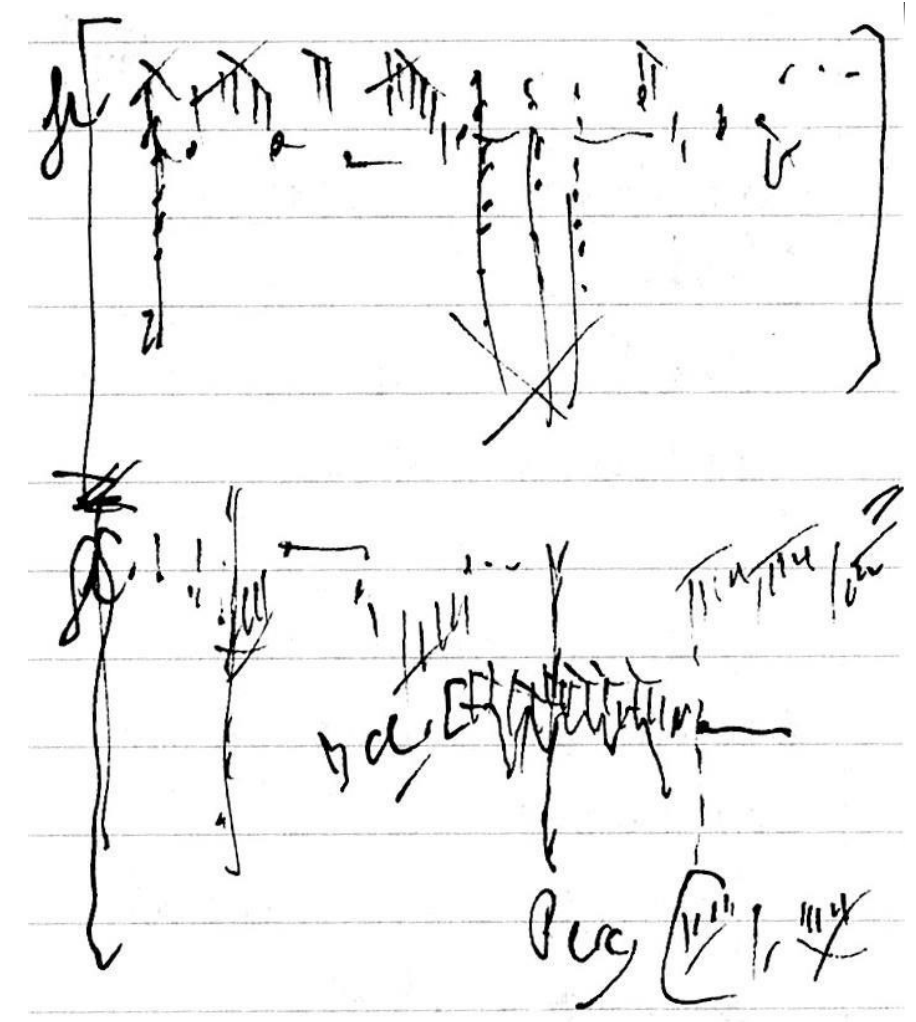

Fig. 9: Pequeno rascunho em canto de página para o começo de Hablad, Gritad, concerto para flauta e orquestra, com o desenho do primeiro gesto da flauta, suas retomadas e os blocos e corte.

Esta dinâmica das imagens abre caminho para o que tenho pensado quanto ao uso do heterogêneo no fluxo musical. Se por muitos anos estivemos aferrados ao paradigma da continuidade por semelhanças e analogias, por relacionar os elementos de modo intelectual, pela mediação de uma representação, outros modos de continuidade podem ser pesados, e o heterogêneo é não só um destes modos, como também um fator importante para o dinamismo do fluxo de escuta. O heterogêneo dispararia incessantemente o embate com a necessidade de invenção de desvios. E este jogo todo não fica preso ao sonoro, ao auditivo, mas a própria música pode ser pensada como modulante entre olho, pele, ouvido, língua, entranhas. Nem se reduz a uma figuração melódica, rítmica ou harmônica.

Com este propósito é que, desde minhas primeiras peças, me valho de mais de uma técnica composicional em uma mesma peça. É também com este propósito que me valho das chamadas técnicas estendidas, para que dois sons seguidos sempre possam abrir caminho para lugares diferentes, para uma polifonia espacial - lembrando Ligeti (2001) e a ideia de efeito estereométrico ${ }^{11}$. Este heterogêneo, quando falando das técnicas instrumentais, vem carregado ainda de outro heterogêneo: a riqueza das vozes e instrumentos 
"desregulados" de cantadores populares, onde cada nota, cada ataque, difere por pressão de arco, dedilhado, local de pinçamento de uma corda, colocação da voz, ponto de contato de dedos e mãos com a pele e madeira de tambores. Diria que aqui a estereometria é transformada em uma espécie de espectrometria, um ritmo microdesenhado pelos parciais do som nos fazendo ouvir uma sobreposição de linhas métricas.

É deste mesmo modo, fazendo com que o que ouvimos ora pareça vir de um lugar, ora de outro, que também não me restrinjo quanto às técnicas ditas harmônicas. 0 modal e o tonal, o tonal e o concreto, técnicas de polarização junto a técnicas espectrais, serialismo e direcionalidade modal, a "ilógica" da diversidade. Neste ponto, vale lembrar o que chamo para mim de "fábula de crescimento pelo meio": um ponto de partida - uma fenda na parede - e a proliferação de vidas em um mesmo espaço, que serve localmente para o surgimento de outras. Se há uma regra geral, esta tem de ser elementar como "crescer em direção à luz", "crescer em contraposição à gravidade", como plantas em uma floresta solta cuja capacidade seletiva determina o caminho, mas que seja pequena para não morrer em um bosque monótono de tulhas ou eucaliptos.

Neste caminho de escrita musical, mesclo estratégias mais gerais e calculadas com outras locais e alucinadas, com alta variabilidade de modos de ataque e, mais recentemente, com a ideia de distender o tempo: esticar as coisas até um certo limite - antes de sua abstração e conversão em pedal, como seriam exemplos algumas obras de Morton Feldman. Distorcer não simplesmente como técnica, mas como simulação de uma escuta que me persegue: ouvir a música como se viesse de trás de uma parede, de dentro de uma tubulação, ou como se estivesse com a cabeça dentro d'água.

\section{Pontos de falsas origens}

Analisando o aspecto rítmico da Sagração da Primavera em aulas, sempre me pergunto quais seriam os esquemas genéticos que teriam permitido sua composição em tão pouco tempo. Meu ponto de apoio são os rascunhos publicados com autorização do compositor em 1969, onde diversos esquemas de repetições e de esqueletos rítmicos são base de grandes passagens (STRAVINSKY, 1969)

Meu primeiro exemplo é aquele que está mesmo na leitura de Pierre Boulez (BOULEZ, 1995, p.87). Não como modo de descobrir uma estrutura, mas como modo de deduzir um algoritmo que me permita refazer esta mesma passagem, ou mesmo fazer outras a partir da mesma fórmula.

No primeiro exemplo, o que temos é uma simples sequência de durações em um ritardando e accelerando escritos por subdivisões e quiálteras que, seccionada por inserção de apojaturas, agrupam sequências com quase o mesmo número de onset. Meu interesse está na simplicidade com que se poderia criar sequências melódicas a partir de sequências de durações regulares (isócronas ou com accelerandi e ritardandi escritos ou mesmo em vai e vens). 

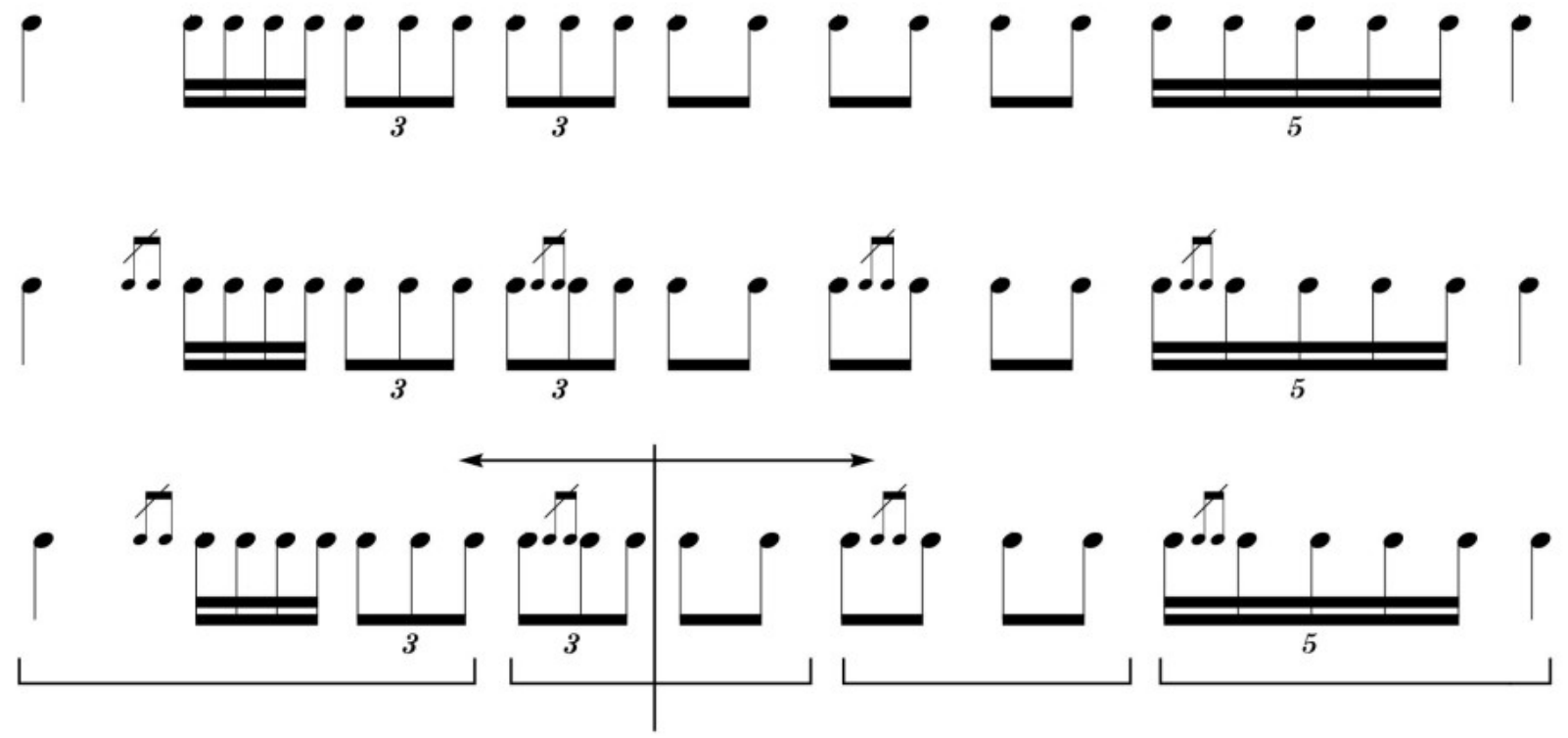

Fig. 10: Esqueleto rítmico do primeiro módulo melódico da Sagração da Primavera, de Igor Stravinsky. Na primeira linha o esqueleto simplesmente, na segunda o esqueleto com apojaturas reagrupando as durações em sequências de 8, 5, 4 e 6 notas.

Um segundo exemplo, ainda pensando nas possibilidades de trabalho a partir do esqueleto temporal, está em Rondes Printanières.

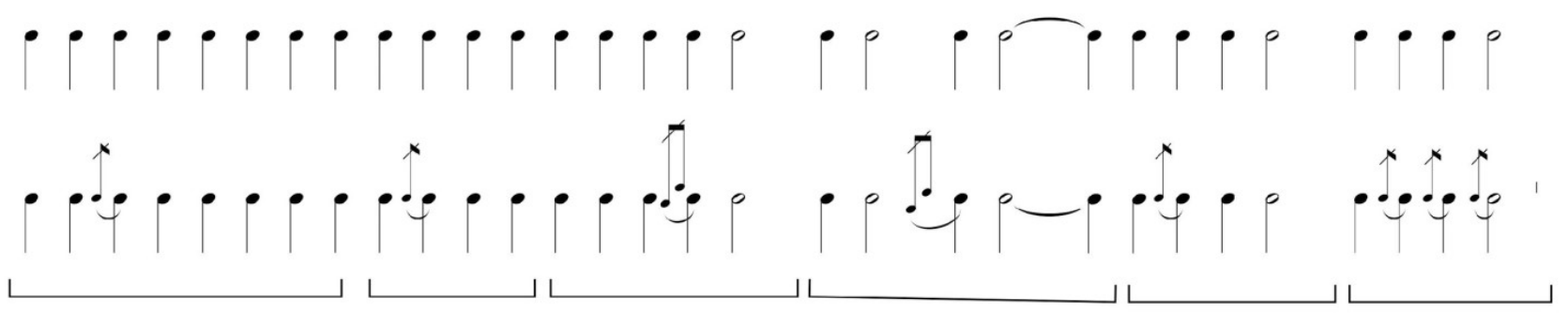

Fig. 11: Esqueleto temporal e desdobramento nas "Rondes Printanières", da Sagraçao da Primavera de Igor Strasvinsky.

Chama a atenção neste esqueleto rítmico, que segue passos muito parecidos com o da melodia do início da Sagração, a sequência de onset entre cada apojatura que agora segue um passo de redução, com uma pequena escapada a este passo: 2, 7, 6, 4, 3, 4, 1, 1, 1 que, com a realização melódica, permite agrupar a sequência ainda de um outro: $8,4,5,4,4,4$.

Este método bastante elementar me levou a um algoritmo de composição que tem por ponto de partida elementos os mais simples possíveis (como, por exemplo, um pulso), os quais passo a passo sofrem um processo de proliferação em suas próprias entranhas. O intervalo entre cada pulso pode dar lugar a uma apojatura, as apojaturas podendo progredir em número de notas e assim por diante. $O$ pulso que nasce estável em uma linha reta pode sofrer curvaturas, as curvaturas podem seguir uma ordem também numérica de ocorrências. As curvaturas se dão a partir de um módulo de curvatura (um intervalo) ou de um molde (uma escala, um conjunto de notas).

Este momento do algoritmo é como a projeção de uma sequência de ataques em uma caixa de ressonância. Outros modos de alteração podem surgir, como, por exem- 
plo, projetar sobre esta mesma sequência acelerações e retardos (em um dos exemplos, expresso nas quiálteras de cinco ou três tempos).

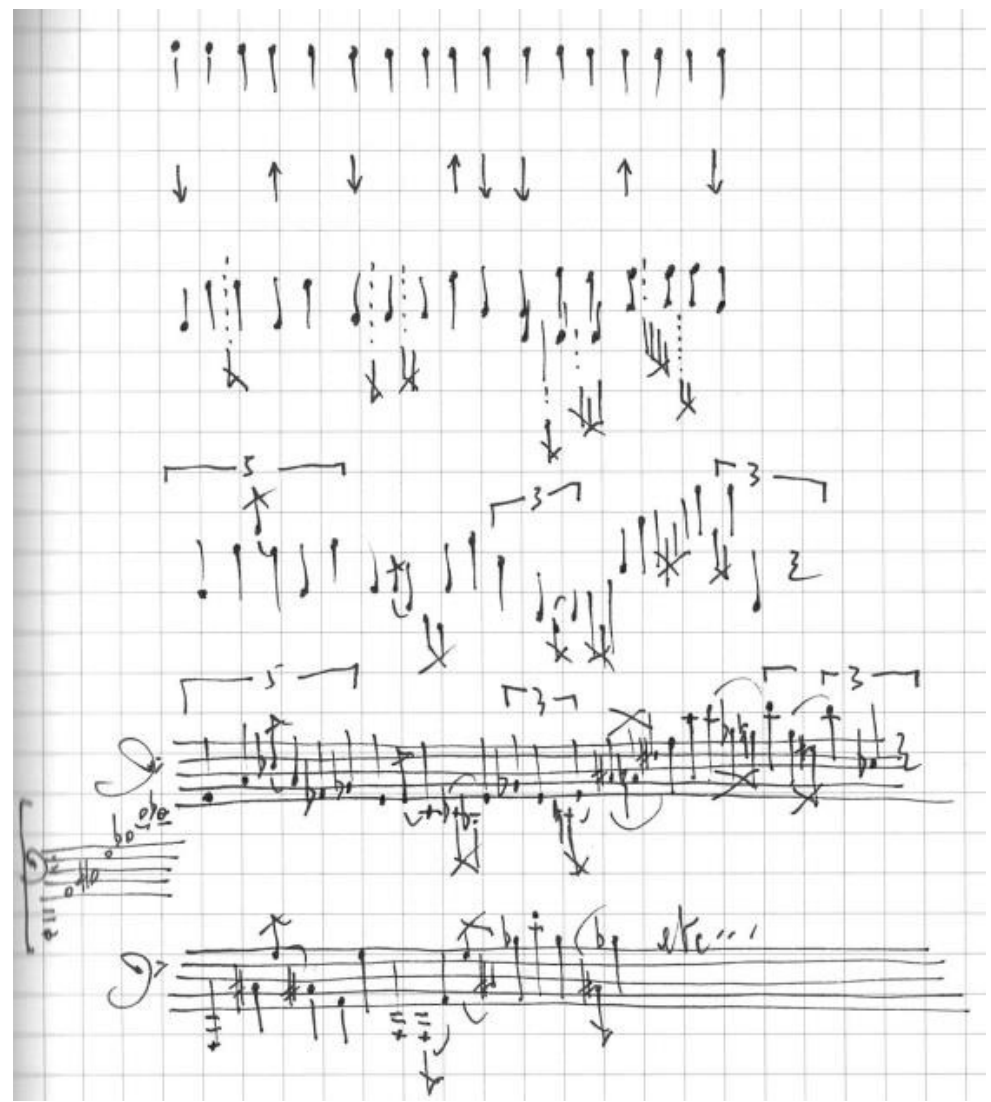

Fig. 12: Rascunho de transformação de uma linha de pulsos por orientação agudo-grave (em um passo que ora repete, ora permuta os valores 2-3), incrustação de apojaturas (em número crescente, em zigue-zague, 1..2...3...2...) e sua ressonância em duas situações distintas: recursividade intervalar e ressonância sobre uma série fixa de alturas.

Um modelo que uso de modo recorrente é aquele proveniente do módulo rítmico de Ionisation, de Varèse, em que Varèse, a cada semínima, não repete nenhuma figura rítmica.

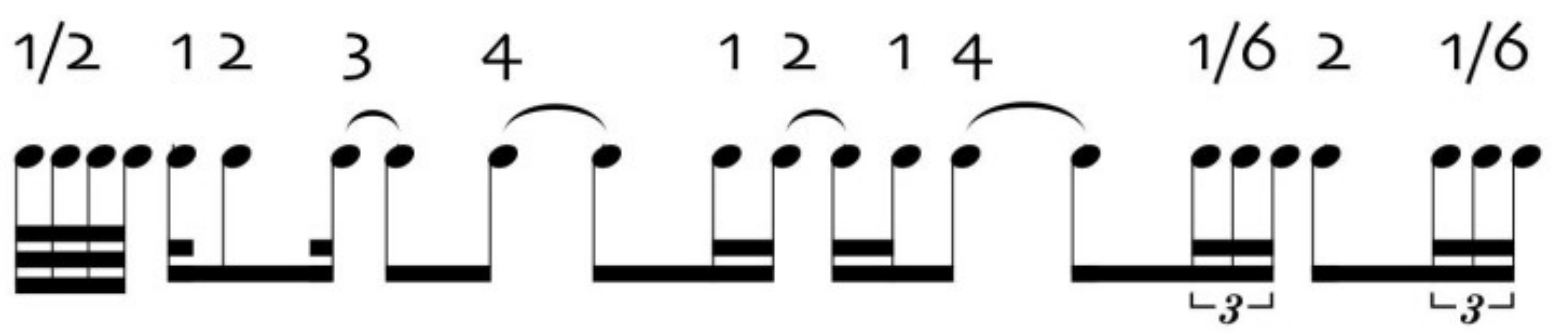

Fig. 13: Rascunho de sequência de durações de Ionisation, de Varèse. Embora as figuras rítmicas sejam recorrentes, as durações seguem uma sequência sem repetição direta, exceção para os dois pequenos grupos (grupo de 4 fusas e grupos de 3 tercinas de colcheias).

Foi a partir desta ideia de não repetição de módulos rítmicos que trabalhei a composição de uma linha melódica para violoncelo (que pode ter figurado ou não em alguma peça solo) (Fig. 14). 


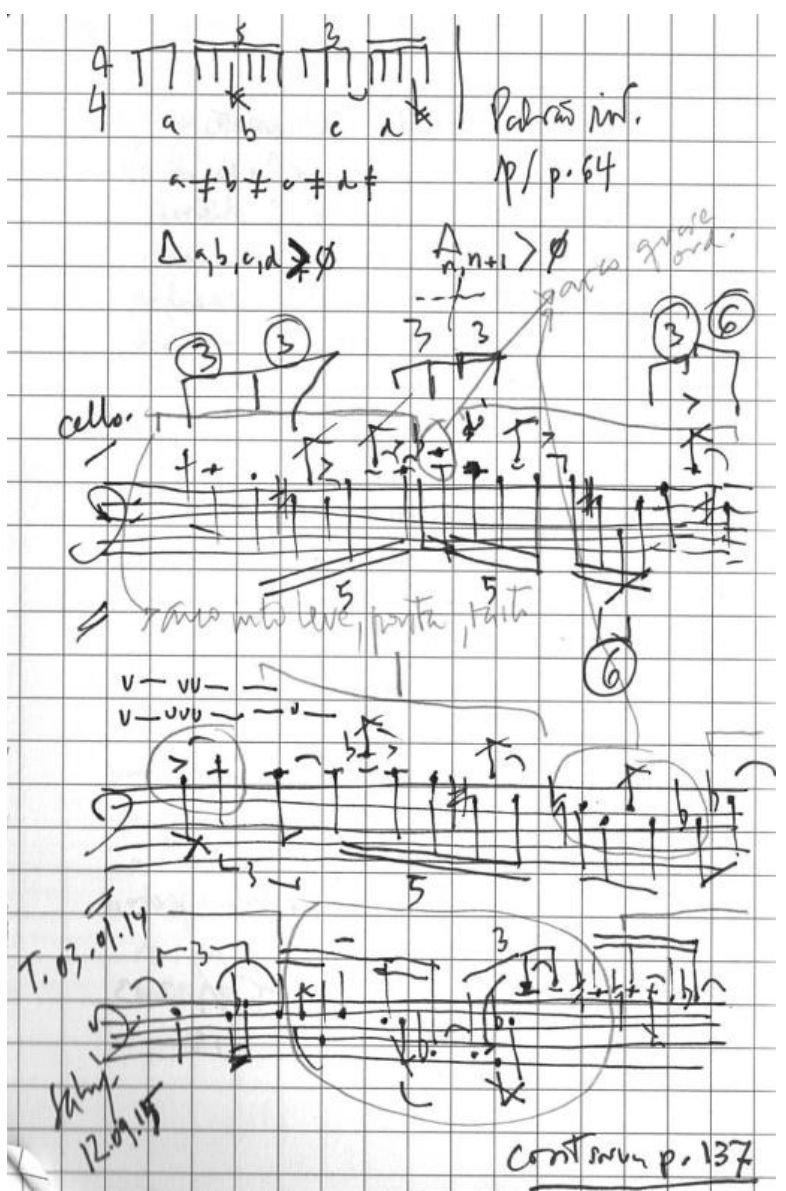

Fig. 14: Rascunho de linha de violoncelo, com algoritmo que tem por matriz recursiva uma sequência de durações em que cada tempo difere em subdivisão com seus vizinhos.

Um ponto que me parece interessante observar aqui é a passagem do uso da apojatura como ornamental a estrutural. A apojatura primeiro passa a ter força de acento métrico, de elemento que indica o começo de uma sequência. Em um segundo momento, esta passagem de ornamento a estrutural se dá pela operação de aumentar o número de notas e de dar alguma importância harmônica - por exemplo o fato de as apojaturas se darem em um conjunto de notas que não faça parte do conjunto ou modelo intervalar da frase que elas seccionam, procedimento que empreguei ao longo da composição de Ritornelo, para flauta e percussão, composta em 1998.

O uso das apojaturas como elementos estruturais não tem por referência apenas Stravinsky e a Sagração da Primavera, tem também o Bach das Variações Goldberg BWV 988 e do segundo movimento de seu Concerto Italiano BWV 971. Poderia subdividir o tema das Variações em dois elementos, o esqueleto harmônico e as diversas ornamentações. Logo na primeira das variações, Bach converte o ornamento, uma bordadura simples, em material principal de condução da variação. Na versão para cravo (BWV 974) do Concerto de oboé em Ré Menor (S935) de Alessandro Marcello, Bach expande o que aparece como ornamento em um elemento estrutural, e a cada nova aparição da figura principal ela se torna mais complexa por subdivisões, o que no original de Marcello está apenas indicado como uma bordadura. 

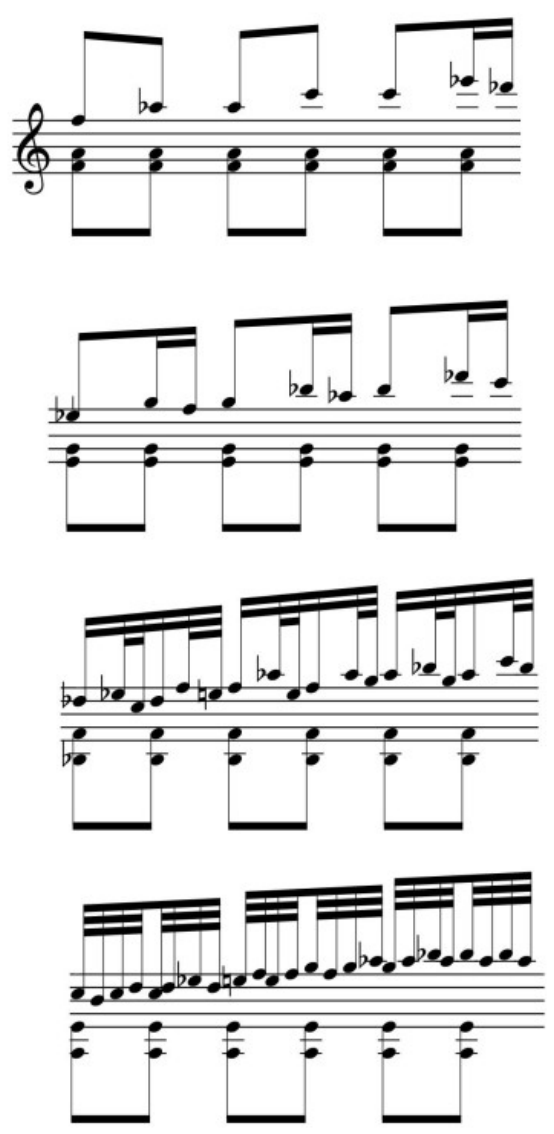

Fig. 15: Três momentos do Adágio, do Concerto de Oboé (S935) de Alessandro Marcello em reescrita de J. S. Bach (BWV 974).

Deste modo, o que em Marcello é simples repetição de uma linha fundamental (arpejo lento de ré menor) ornamentada, em Bach descreve um ciclo de adensamento de uma figura melódica.

Compreendida como estruturais, as apojaturas e bordaduras diversas podem ser tratadas como inserções, incrustações, pontos em que se é possível trabalhar com variações de modo de ataque, timbre, prolongação de tempo, alteração no espaço harmônico e no âmbito de tessitura. Dado seu aspecto estrutural possível, emprego tais recursos em minhas composições conforme três modos distintos: (1) incrustações que constituem ciclos regulares, curtos, sobrepostos, como uma respiração; (2) desenhando um acúmulo (adensamento, rarefação), tendo Bach por referência e (3) através do uso de permutações (estratégia serial para suspensão do tempo teleológico).

Como há alteração na projeção sonora quando empregamos tais recursos em instrumentos de sopro e cordas, eles me servem também para desenhar a espacialidade da peça, sua estereometria: momentos mais localizados, momentos difusos, momentos dirigidos, móveis ou estáticos. 


\section{Kairos-Chronos}

Fiz este pequeno parêntese mais técnico quanto às estratégias de escrita por ele ser recorrente em um conjunto de peças que tenho trabalhado desde 2012, a série Kai$\operatorname{ros}^{12}$. Este conjunto de composições, ainda em trabalho, nasceu de uma conversa musical com o compositor e colega Roberto Victório, cuja série Chronos é bastante conhecida entre instrumentistas brasileiros. A série Chronos é extremamente radical, com um alto grau de invenção que a todo tempo leva a música aos seus limites.

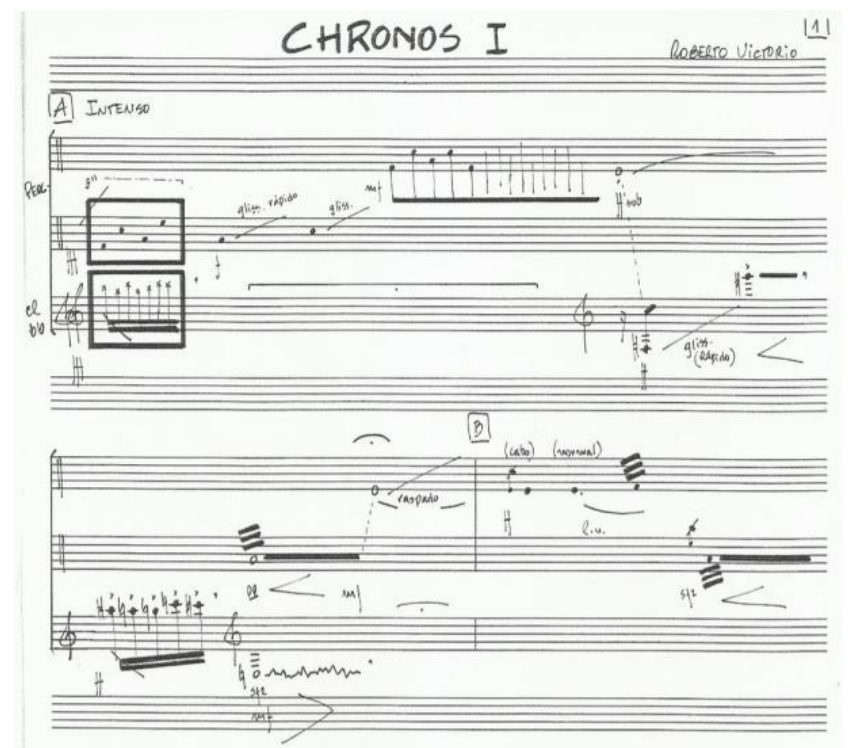

Fig 16: Partitura manuscrita do início de Chronos I, para clarinete e contrabaixo, de Roberto Victório.

Na peça de Victório, a cada linha da partitura, é como se o compositor fosse para um outro mundo musical, tudo fluindo por consistência local, por reação em cadeia, mesmo que entre blocos de textura distintos. A esta série de composições, Victório acrescentou ainda uma segunda mais irruptiva ainda do que a primeira, os Aroes. Nestas, a todo tempo o compositor alterna dois mundos temporais: o tempo calculado, subdividido sob uma norma isócrona, com frases claras e complementaridade entre as figuras tocadas pelos instrumentos, e o tempo flutuante, solto, onde os instrumentos tocam seus mundos de ruídos. 

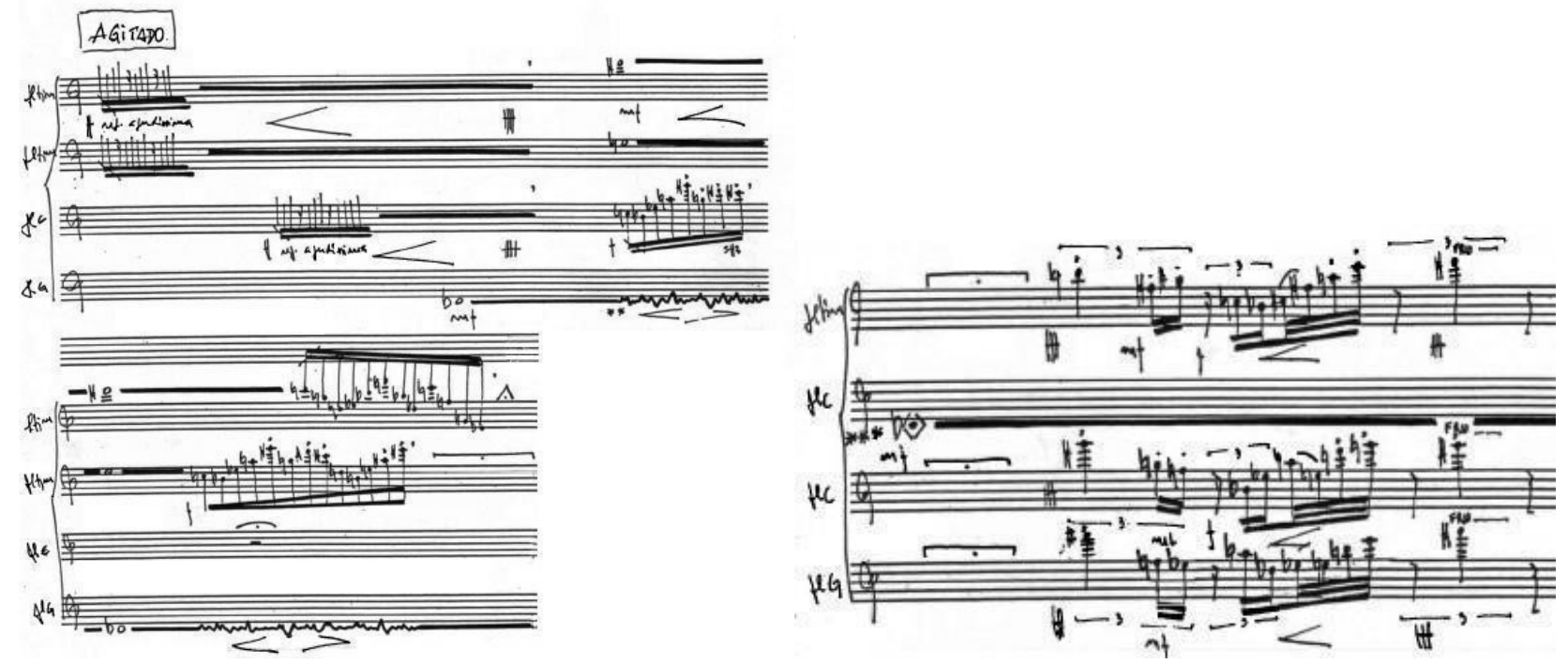

Fig. 17: Partitura manuscrita de dois momentos de Aroe Enoware, de Roberto Victório, para quarteto de flautas. 0 momento de escrita livre e o de escrita medida.

Este segundo lugar, da escrita dos ruídos, é o lugar das passagens improvisadas com material predeterminado. É também o lugar onde entram os instrumentos indígenas, flautas de bambu, apitos, gritos; em Chronos IX, especialmente o grito gutural que se articula com passagens rítmicas de frases cortantes; em Aroe, a gritaria dos apitos; em Vatam, o ruído do contrabaixo no agudo, arco raspado.

A partir desta consideração sobre o tempo, há um bom tempo distingo três modos de composição no conjunto de peças que escrevo: os Ritornelos, os Lamentos e os Kairos. Os Ritornelos são peças em que há (1) grande e rápida alternância nos modos de ataque, (2) tratamento da tessitura por grandes saltos a partir de cantos de pássaros, (3) escrita rítmica micrométrica, (3) polifonia intensa de materiais heterogêneos e (4) desdobramento de material composicional por módulos recursivos e prolongamento analítico. Os Lamentos são peças lentas, módulos longos, geralmente conduzidos por uma linha de passus duriusculus com cromatismo descendente. A harmonia das peças é geralmente conduzida por reescrita e, no mais das vezes, junto com o cromatismo dos passus duriusculus, tomo por matriz recursiva a harmonia dos Motetos de Passo do compositor mineiro do século XVIII-XIX Manoel Dias de Oliveira. Já os Kairos são uma série mais recente e têm por base a decisão e os pontos de ruptura instantâneos ${ }^{13}$. Nos Kairos retomo a ideia de alternar dois mundos presentes na música de Roberto Victório.

Claro que retomo a meu modo, e isto se reflete em dois conjuntos de obras que venho trabalhando há um bom tempo, os Ritornelos de alta densidade polifônica e os Lamentos, com suas grandes praias de sons estáticos. Entrelaço assim dois mundos temporais, aquele mundo medido através de uma hipernotação de ritmo, com uma escrita granular, em contraponto ao mundo lento, arrastado dos sons livres, sonoridades como a de carros de bois - um mergulho dentro do espectro e sua escuta alongada. São dois modos distintos de fazer vibrar um ou mais campos de ressonância, o que define uma harmonia. 
Um gesto, um risco marcado pelo fluxo de energia com tendência clara e súbita. Um fluxo rápido, com começo, meio e fim, e que não conversa com outros gestos. Um gesto vale por si. Não precisa ser explicado. O gesto é um lance e se distingue de uma textura que, ao invés de irruptiva, é distendida. A série Kairos articula estes dois mundos, o do gesto e o da textura estática, parada sobre uma nota, sobre um espectro, sobre uma trama fina granular - uma série de trêmulos, por exemplo - ou um vai e vem lento de gangorras ou balanços em um parque.

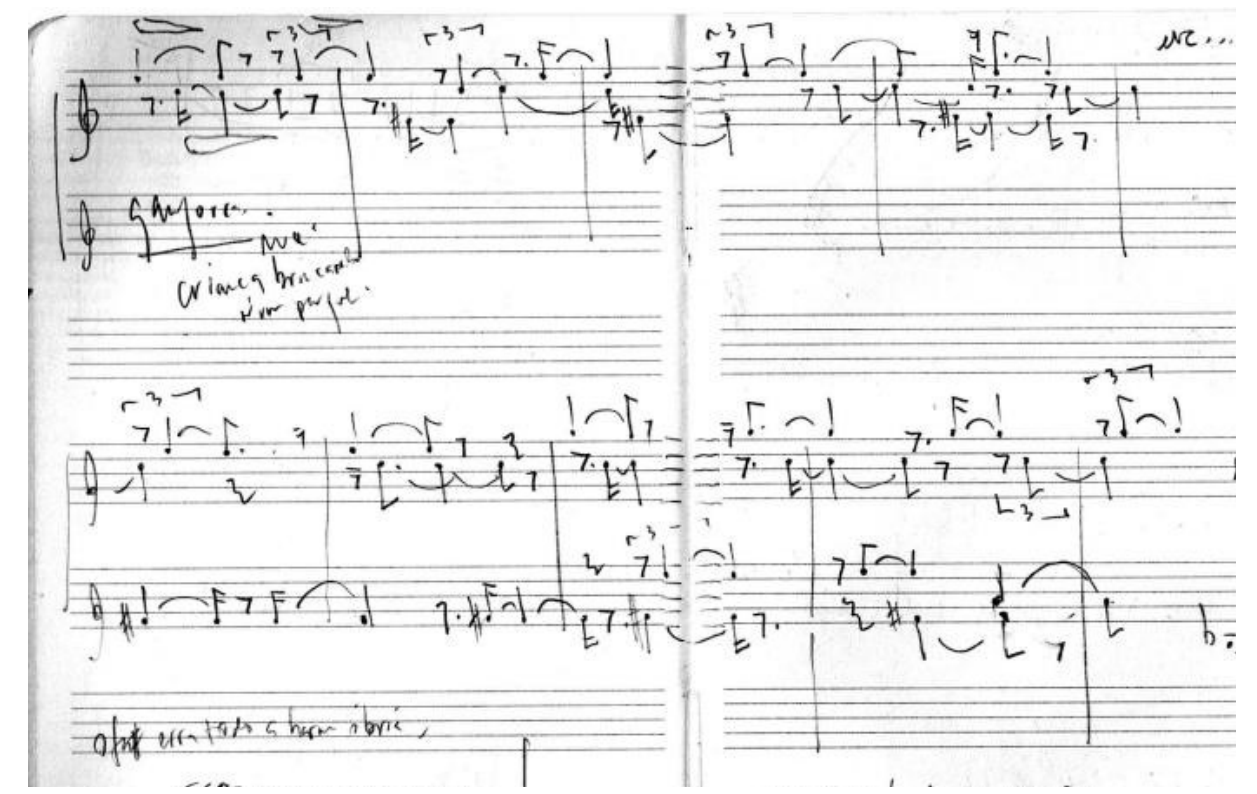

Fig. 18: Anotação rápida da ideia de série de gangorras e balanços realizada no Parque da Água Branca (SP), com textura distendida formada por ondulações sobrepostas.

Do modo como compreendo Kairos, ele é o corte, o momento decisivo, o instante da incisão para cortar o espaço sonoro que suspende o fluxo de um espaço para fazer vir outro, e onde qualquer volta não será a do mesmo, já que o corte instaura antes e depois, instaura conexões, abre caminhos de escuta que sem ele não apareceriam.

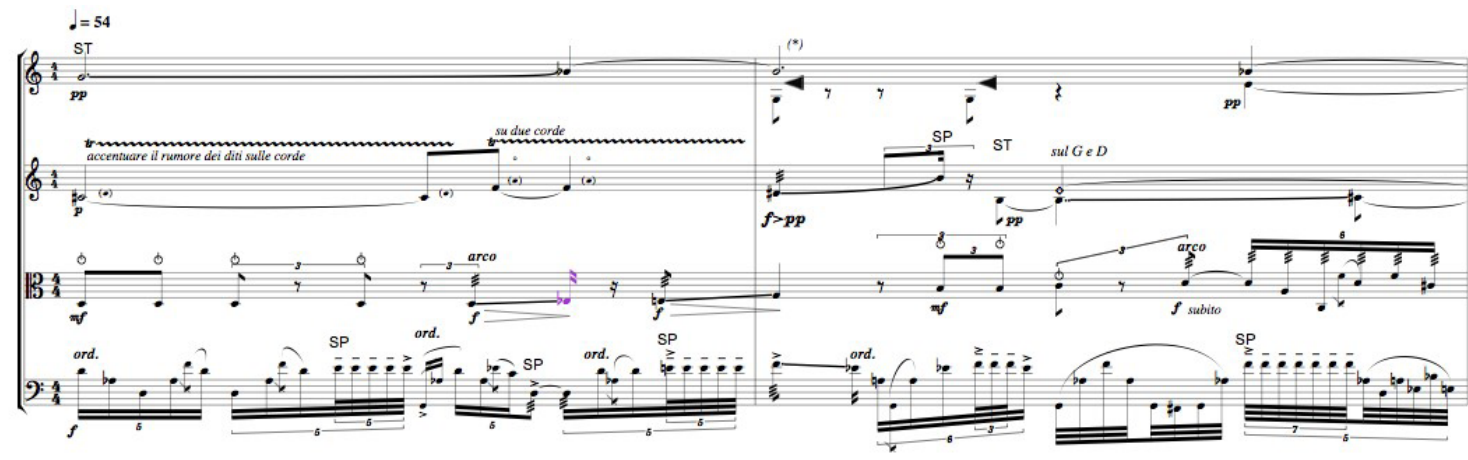




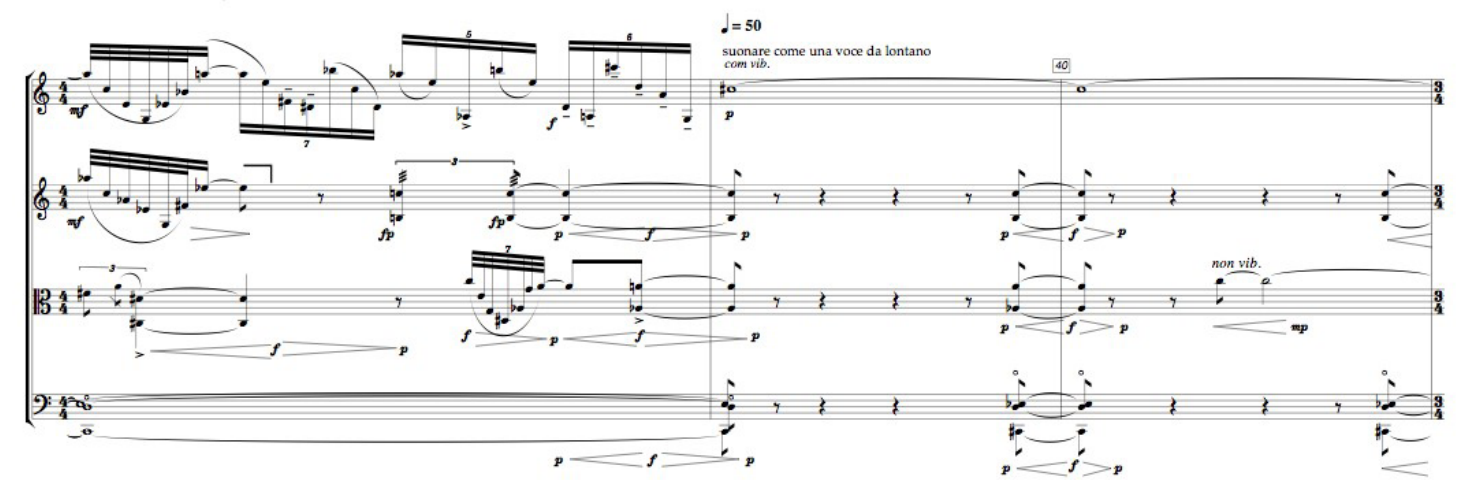

Fig. 19: Dois momentos do quarteto Pássaros de Corda (cps.1-2 e 38-40): (1) microcortes que desviam a atenção da escuta e interferem na escuta do sentido da linha contínua; (2) grande corte com interrupção de continuidade movida, o qual, por sua vez, tem escuta desviada por irrupções fortes.

De fato, não relaciono estes dois mundos, apenas os confronto e deixo que se relacionem, que um module o outro sem um sistema de normas que reja tais relações: as imagens $A$ e $B$ se relacionam apenas porque se tocam em algum ponto de simultaneidade espaço-temporal; estão justapostas, sobrepostas, seja como imagens-percepção, seja como imagens-lembrança. Não significa que não me dedique por vezes ao desdobramento de elementos, empregando métodos mais tradicionais e mesmo as anamorfoses, como, aliás, exemplifiquei acima com a transformação de pulsos em linhas. Como observei antes, diversas técnicas composicionais entram em ação: as técnicas seriais, as anamorfoses adquiridas da música eletroacústica, os desdobramentos algorítmicos aprendidos com o uso de programas de auxílio à composição, como OpenMusic (da família Patchwork, que uso desde 1998), MAX/MSP (sobretudo ferramentas de operação com listas), sistemas simples de permutação e frase comentário (aprendido de Messiaen), filtros harmônicos (aprendidos de Brian Ferneyhough e da música espectral). Tais técnicas servem para a definição de pequenos territórios sonoro-musicais, os quais, postos lado a lado, manifestam suas distâncias.

Aqui me valho de uma observação do pintor Paul Klee, a qual retomei em alguns artigos: "Do ponto de vista psíquico, a justaposição de fortes contrastes engendra uma expressão cheia de força. A inserção de um meio de ligação entre os contrastes os afasta mutuamente e enfraquece a expressão" (KLEE, 1980, p.319). Entra em jogo então o que chamei de tempo vertical ${ }^{14}$, o tempo que irrompe entre dois objetos, entre dois territórios constituídos e aparentemente estáveis. Este tempo, diferente do tempo distendido, se dá como a duração bergsoniana. Ele manifesta sua espessura em um só ponto, é o ponto de invenção em que o ouvinte é retirado de algum lugar e lançado em outro, onde a distância enfrentada colocará mais ou menos operadores na busca da continuidade. Diria que meu trabalho composicional busca sempre a continuidade

\footnotetext{
14 Esta noção de tempo vertical é muito diferente daquela proposta por Kramer em The time of music (1988). Em seu livro, Kramer define um tempo vertical que seria aquele presente em formas como as Moment Form de Stockhausen, como momento que condensaria de modo quase vertical um espaço temporal horizontal mais amplo, ou ainda a escuta do momento, das ilhas de sons como em diversas obras dos compositores da escola de Nova York, a música estática de Christian Wolff (KRAMER, 1988, p.55 e 384 et seq.). 0 que proponho aqui não diz respeito ao momento ou ao instante, mas ao intervalo vertical, o entretempos, referindo Deleuze em Cinema-Imagem-Tempo. 0 espaço intensivo que acontece entre domínios extensivos, entre um antes formado e um depois que se forma, lugar em que se dá o nascimento de operadores de continuidade, dos mais simples que reconhecem no que vem aquilo que vinha, aos mais complexos de modulação entre objetos totalmente distintos, a "expressão cheia de forças", como refere Klee.
} 
concreta, e não a unidade na ideia. Diferentemente de toda uma corrente que desde o final do século XVIII busca a continuidade por uma ideia que identifique e unifique os elementos de um curso, me coloco ao lado de pensadores que tentam pensar a continuidade fora da obrigatória unidade de ideia, um modo de trabalhar o heterogêneo, o mestiço, o disparate, o diferente. Alguns procedimentos de apaziguamento das diferenças talvez venham, vez ou outra, roubando o que Eduardo Viveiros de Castro observou entre os Araweté sobre a arte de falar muitas vozes em um só fluxo vocálico, fazendo-as confundir pelo uso de uma sonoridade e ritmos semelhantes ${ }^{15}$.

É deste modo que compreendo três modos de trabalhar continuidades: por cortes, por anamorfoses, por tramas.

Escrever música como uma viagem dentro som, como imaginava Scelsi. Um ponto de partida - que não necessariamente estará no começo da peça: um jogo de ressonâncias próximas, passeando por sonoridades vizinhas até onde a viagem permitir. $O$ que importa é que a viagem seja livre, assim a todo tempo poderei trair as ideias iniciais simplesmente porque terei encontrado outras.

A continuidade é dada pelo balanço no fluxo de energia, do jogo entre cheio e vazio, focado e desfocado, denso e não denso, leve... existiria um fluxo de energia, passagem de energia entre um som e outro. Uma energia seria a presença de uma periodicidade, de um sistema de oscilação. A energia, o fluxo de energia, dizendo respeito a uma cadeia que garanta o movimento oscilatório (regular ou irregular). Uma regularidade é necessária, um mínimo para que objeto se torne notável, para que nasça uma forma. Se no grave podemos ser rápidos ou lentos - lentos porque as notas soam por longo tempo -, no agudo isto só se dá se a nota for sustentada. Mesmo assim, a energia pode se desgastar, perder sua força de manutenção, de tensão. Cada elemento deve, assim, ser um tensor, mantendo a corda da escuta esticada, para que o fluxo passe - mas não tanto - a ponto de se tornar um nó por onde nada flui. É difícil pensar na escuta do som, esta ideia que é visual e que observo nos objetos físicos palpáveis. Estamos entre o empírico e a fábula. Tento ouvir um feixe de muitos sons, com tendência a se tornar mais e mais denso, e que interrompido deixa passar toda energia de seu movimento para uma nota longa que lhe segue.

O que se passa, então? É como uma apojatura com salto amplo... A nota de chegada recolhe a energia da força do salto, da dinâmica e da duração.

\footnotetext{
15 "O canto xamanístico é uma canção de canções, um discurso de discursos, é polilógico. Quase nunca um xamã muda de timbre ou de tom para indicar que mudou o sujeito da enunciação das frases cantadas; parte dessa informação depende do contexto interno, parte do contexto externa, e parte de um procedimento metalinguístico [...] (CASTRO, 1986, p.548).
} 


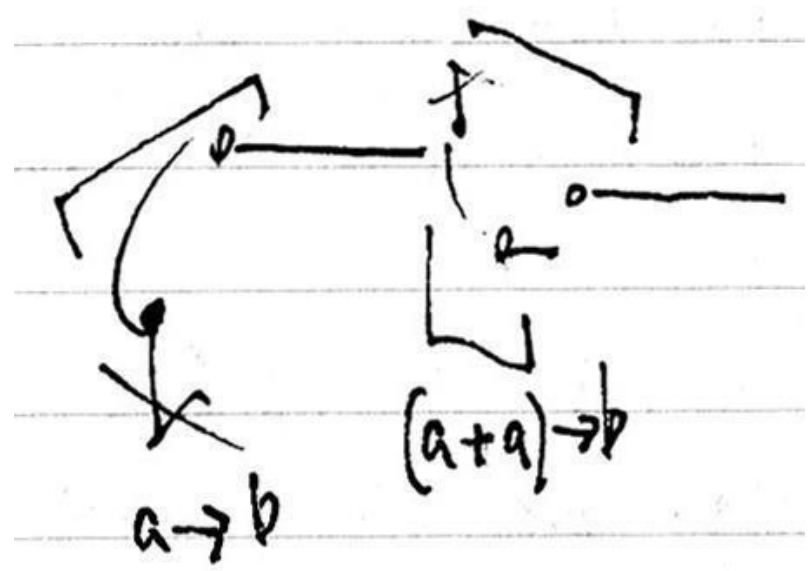

Fig. 20: Apojaturas com grandes saltos em que a energia do salto é como que recolhida na nota longa que as segue.

Não há tema nem material temático ou composicional que funcione como ideia principal, há só um ponto de partida e um eixo de recorrência. Começo por gesto, uma frase muito curta de certa sonoridade que gire sobre si mesma, a ela outras linhas serão agregadas, e talvez esta primeira se perca, pare de ser desdobrada por recursividade, dentro de um todo polifônico sem pensar neste todo enquanto relação de ideias, mas relação de fluxos: fluxos longos, fluxos curtos, microcortes, microlinhas.

Penso ainda no todo textural, em dar lugar a pontos de fusão ou fissão sonora entre linhas quando sobrepostas. Amálgamas, entrelaçamentos, empacotamentos... Compor sobretudo por tramas e escrever linhas que acabem ganhando continuidade; deixar as linhas e se lançar a outras. Cada linha, cada gesto, pode se autonomizar e ser disparador de outras linhas. Por vezes submeter tudo a um controle geral por meio de um corte brutal ou eliminar alguns instrumentos trazendo à tona um solo, embora aqui surja um problema que é o mecanismo retórico de pergunta e resposta que busco evitar.

Os instrumentos podem trabalhar ora em solos, ora em duplas com relações do tipo ataque ressonância ou em proximidades de alturas para forçar o aparecimento de fusões por batimentos, e ainda em polifonias extremamente densas, mesmo se a duas vozes. Escrever música como quem escreve um bilhete, lançando-se no ponto de colisão das formas que se atualizam e do fluxo caótico que vem do futuro. Como propõe a filosofia de Gilles Deleuze, a flecha do tempo é invertida, ela vem do futuro. Do futuro vem o caos, a força sem forma, um pacote infinito de energia (potencial de transformação) que se choca com o presente e que carrega consigo algumas estruturas e, sobretudo, operadores modulantes. A continuidade sendo a conversão constante de operadores e estruturas e vice-versa, como lembra Simondon ao falar sobre o que denominou alagmática.

Fecho este texto sobre processo de criação musical com duas páginas de rascunho de Dois pássaros de papel, para flauta e clarinete baixos. Na primeira imagem, os gestos que são transformados em módulos recorrentes, que não apenas os mudo de lugar, os faço transitar entre os instrumentos, como também os modifico por anamorfoses diversa (transposições, pequenas permutações, substituição de notas por pausas ou por apojaturas e grupeto, mudanças pontuais de articulação etc.). Na segunda imagem, processo de permutação nas posições dos módulos e passagem de um módulo a outro 
por processo de lento abandono dos primeiros no tipo AABABCBCACDBDCDBEBDEFGEF. Este procedimento vem, novamente, de análise de Sagração da Primavera, da parte central da Action rituelle des ancêtres ( $\mathrm{n}-$ de ensaio 135). Stravinsky passa de A a D em um movimento de rondas progressivas, modelo que tenho retomado constantemente: $A B A B C-A B A B C-A B D A B C D C D D$. O que interessa neste modelo é abraçar uma composição como quem escreve por justaposições, entrelaçamentos e cortes, como já havia proposto antes, em meu livro Música e Repetição,.

Estes dois últimos exemplos, os deixo aqui na forma de rascunho dos Pássaros..., em anotação rápida; talvez o lápis e o papel tenham esta potência de registrar as velocidades de pensamento e escuta que a partitura limpa digital não permite.

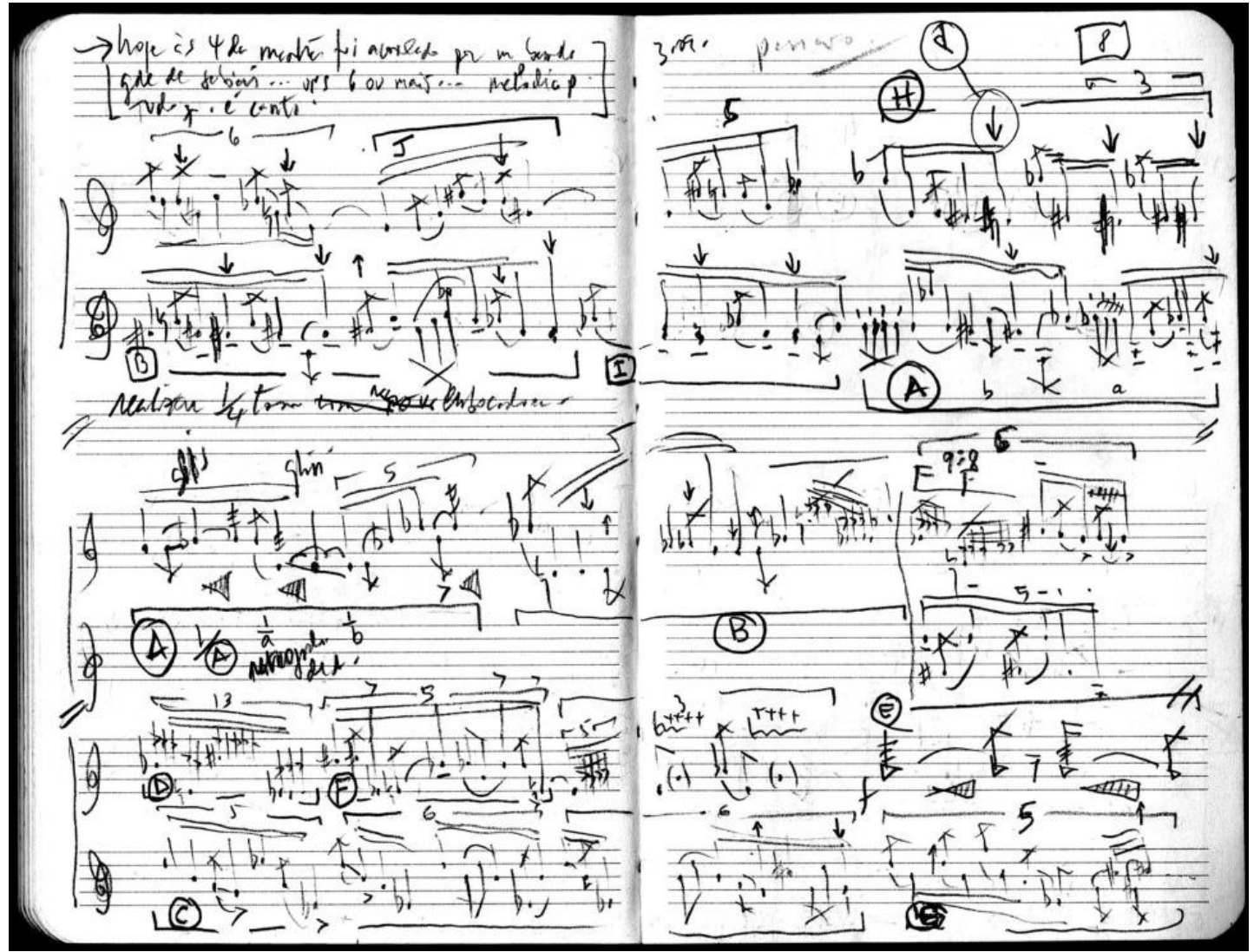




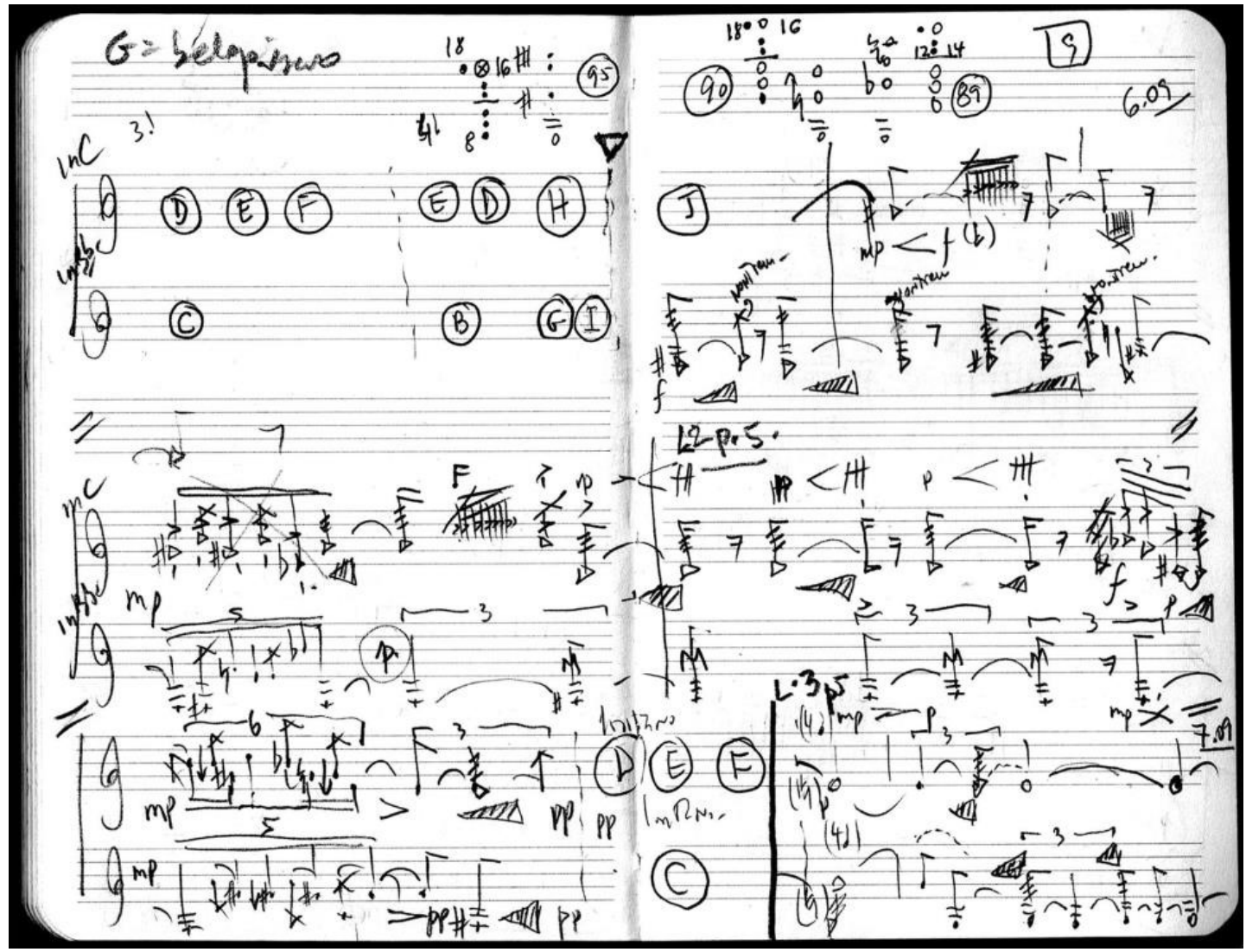

Fig. 21: Duas páginas do rascunho de Dois pássaros de papel, para flauta e clarinete baixos.

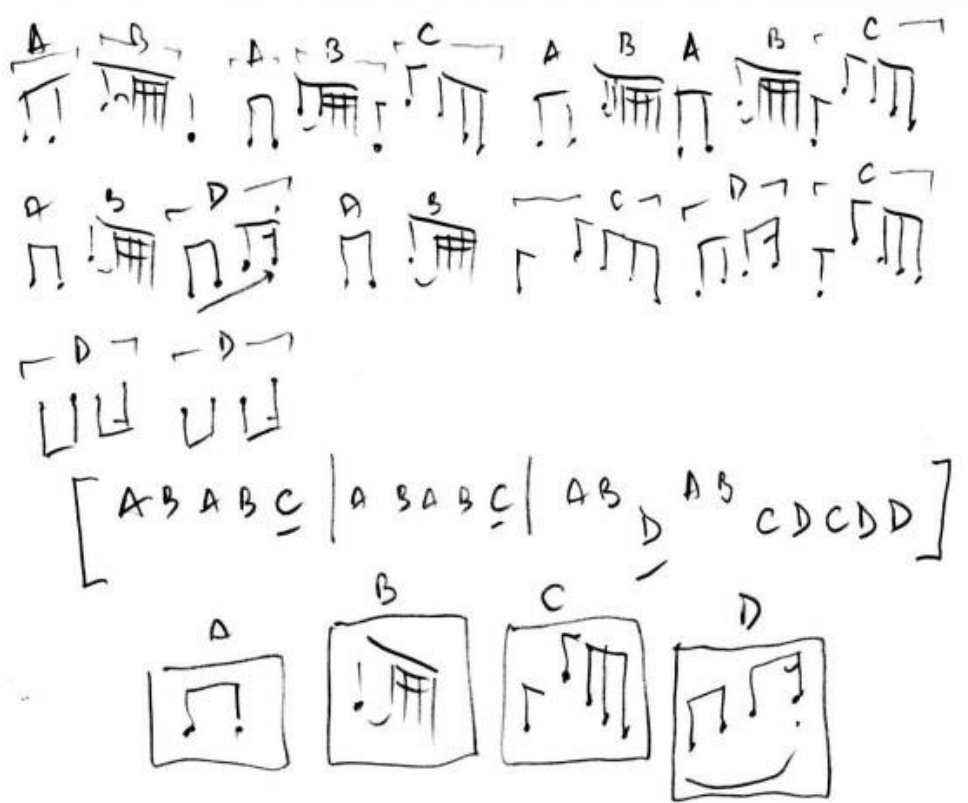

Fig. 22: Análise visual em escrita rápida, da parte central da Action rituelle des ancêtres, da Sagração da Primavera, destacando a sequência rondó livre dos gestos musicais que Stravinsky alterna.

Escrever uma música simples, como um desenho esquecido em um caderno que será jogado fora. Como sempre, o tempo finge que passa. Escrita cursiva, ou melhor, recursiva, de modo a sempre manter viva a continuidade - não deixar a máquina parar. 
Tudo pode mudar, mas a energia não pode parar de fluir de um ponto a outro. E resolver todos problemas que a peça propõe de modo local, sem um plano predeterminado, tipo: como sair de uma nota repetida, como dar um passo para além de um momento de notas em lontano...

\section{Referências}

AGAWU, K. Representing African Music. Nova York: Routledge, 2003.

AROM, Simha. Une méthode pour la transcription de polyphonies et polyrythmies de tradition orale. Revue de musicologie, Paris, Société française de Musicologie, v. 59, n. 2, 1973.

BERGSON, H. Matéria e memória. São Paulo: Martins Fontes, 1990 [1939].

BERRY, Wallace. Structural Functions in Music. Englewood Cliffs: Dover, 1987.

BONAFÉ, Valéria M. Estratégias composicionais de Luciano Berio a partir de uma análise da Sonata per Pianoforte (2001). Dissertação (Mestrado em música) - Escola de Comunicações e Arte, Universidade de São Paulo, São Paulo, 2011.

BOULEZ, Pierre. Points de repère l: imaginer. Paris: Christian Bourgois, 1995.

CAMPILLO, Antonio. Aión, Chrónos y Kairós (la concépcion del tiempo en la Grecia Clássica). La(s) Otra(s) Historia(s), Bergara, Departamento de Historia UNED, n. 3, 1991.

CASTELLANI, Felipe Merker. Textura-Figura-Gesto: O dinamismo processual na composição contemporânea. In: ENCONTRO DE TEORIA E ANÁLISE MUSICAL UNESPUSP-UNICAMP, 2., 2011, São Paulo. Anais [...]. São Paulo: Unesp, 2011. p. 188-199.

CASTRO, Eduardo Viveiros. Araweté, os deuses canibais. Rio de Janeiro: Zahar, 1986.

DELEUZE, Gilles; GUATTARI, Felix. Mille Plateaux. Paris: Minuit, 1980.

DELEUZE, Gilles. Aula de 20 de abril de 1982. Disponível em: http://webdeleuze.com. fr/archive.

DELEUZE, Gilles. Cinema 1: l'image mouvement. Paris: Minuit, 1983.

DUNSBY, Jonathan. Considerations of Texture. Music \& Letters, Oxford University Press, v. 70, n. 1, p. 46-57, feb. 1989. 
FERRAZ, S. Análise e percepção textural: Peça VII, de 10 Peças para de Gyorgy Ligeti. Cadernos de Estudo: Análise Musical, São Paulo, Através, n. 3, p. 68-79, 1990.

FERRAZ, S. Kairos: ponto de ruptura. OuvirOUver, Uberlândia, UFU. v. 11, n. 1, p. 34-52, 2015.

FERRAZ, S. Páginas sobre tempo e espaço na composição musical (caderno amarelo espiral). In: XAVIER, Jussara et al. (org.). Tubo de Ensaio: Composição [Interseções + Intervenções]. 1. ed. Florianópolis: Instituto Meyer Filho, 2016.

FRISCH, Johan Dalgas. Vozes da Amazônia. São Paulo: Hifi-Sabiá, 1963. 1 disco vinil, 33rpm, estereofônico.

KLEE, Paul. La Pensée Créatrice. Paris: Dessain et Tolra, 1980.

KRAMER, Jonathan. The time of music. New York: Schirmers, 1988.

LACERDA, Marcos. Música Instrumental no Benim. São Paulo: Edusp. 2014.

LIGETI, G. Neuf essais sur la musique. Genève: Contrechamps, 2001.

MÂCHE, F.-Bernard. Musique, mythe, nature ou les Dauphins d'Arion. Paris: Klincksieck, 1986.

MCDERMOTT, J. H.; SIMONCELLI, E. P. Sound texture perception via statistics of the auditory periphery: evidence from sound synthesis. Neuron, v. 71, n. 5, 2011.

PICASSO, Pablo. Propos sur l'art. Paris: Gallimard, 1998.

RUWET, Nicolas. Méthode d'Analyse en Musicologie. Revue Belge de Musicologie / Belgisch Tijdschrift voor Muziekwetenschap, v. 20, n. 1/4, 1966.

SIMONDON, Gilbert. L'individuation à la lumière des notions de forme et d'information. Grenoble: Millon, 2005.

SIMONDON, Gilbert. Imagination et Invention (1965-1966). Paris: Editions de la Transparence, 2008.

SOLOMOS, Makis. De la musique au son. L'émergence du son dans la musique des XXeXXIe siècles. Paris: Presses Universitaires de Rennes, 2013.

STOÏANOVA, Ivanka. Luciano Berio, Chemins en musique. Paris: Richard-Masse, 1985. 
STRAVINSKY, I. The Rite of spring: Sketches 1911-1913. Nevers: Boosey \& Hawkes, 1969.

VIELLIARD, Jacques. Cantos de aves do Brasil. Campinas: Unicamp, CNPq e SBO, 1995. $1 C D$, estereofônico.

VON UEXKHÜLL, Jakob. Milieu animal et milieu humain. Paris: Payot, 2010 [1956].

VUYLSTEKE, Michel. Musiques traditionnelles vivantes. n5. Paris: RTF. 1970. 1 disco vinil, 33rpm mono. 